\title{
The Ludovisi "throne", the Boston "throne" and the Warren cup: Retrospective works or forgeries?
}

\begin{abstract}
The Ludovisi and Boston "thrones" are among the most discussed monuments in the history of art. It is here argued that certain details on the "thrones" find their closest parallels among artefacts of the Augustan period such as decorative reliefs and candelabra, Arretine ware and silver work: notably the so-called Warren cup in the British Museum. The "thrones" cannot therefore be dated to the early Classical period. But does that mean that they are Roman retrospective works? Both the "thrones" and lately also the Warren cup have been regarded by some scholars as forgeries. The author of this article strongly suspects that all three were created in the late $19^{\text {th }}$ century.
\end{abstract}

There are certain enigmas in Ancient art which continue to worry the collective subconsciousness of art historians. One is the authenticity of the so-called Boston "throne" (FIGS. 3$4 \mathrm{a}-\mathrm{b}$ ), and, to a lesser degree, the Ludovisi "throne" (FIGS. 1-2 a-b). It is like exploring a loose tooth with the tip of the tongue. You do it now and then, to feel that it is dangling, but still in place.

The debate over the so-called "thrones" has been going on since they appeared on the Roman art market at the end of the nineteenth century. In 1892, a few years after its discovery in 1887, E. Petersen published the Ludovisi "throne" as an Early Classical work (around 470 BC). ${ }^{1}$ In a long and well-researched article from 1911, F. Studniczka declared both the Boston "throne" and the Ludovisi "throne" to be genuine works of the $5^{\text {th }}$ century BC with approximately the same dating as Petersen, ${ }^{2}$ and the authority of these two scholars more or less stifled divergent opinions. In 1929 a serious attack on the Boston "throne" was delivered by A. von Gerkan, ${ }^{3}$ but only in the nineteen fifties and sixties were further critical voices heard. ${ }^{4}$

\footnotetext{
${ }^{1}$ Petersen 1892.

${ }^{2}$ Studniczka 1911.

${ }^{3}$ Von Gerkan 1929.

${ }^{4}$ Cellini 1955; Baroni 1961; Alscher 1963. In 1946 J. Colin declared that the Boston "throne" could not be a 5th century work, but he believed it to be a retrospective work of the Tiberian period, not a forgery (Colin 1946, especially 139-172).
} 


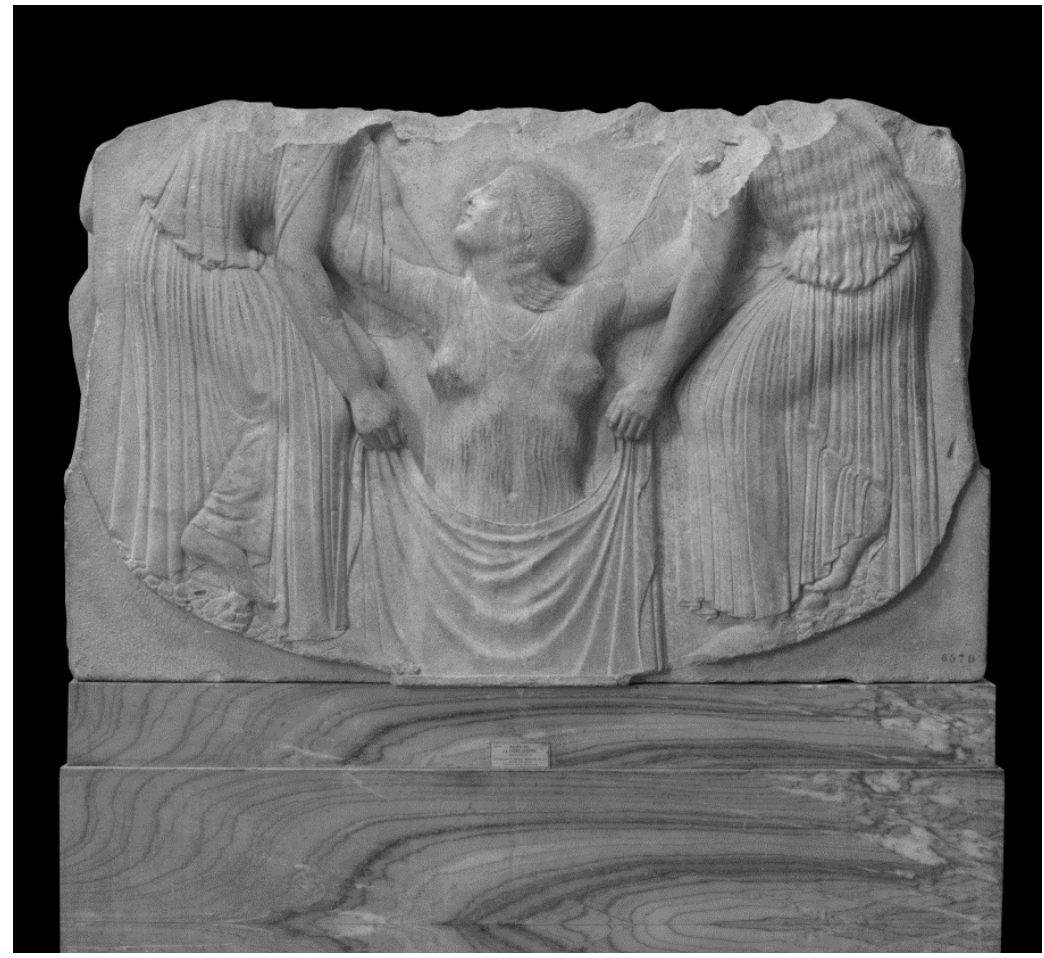

FIG. 1 - The Ludovisi "throne”, front. Rome, Palazzo Altemps. Photo: Deutsches Archäologisches Institut.
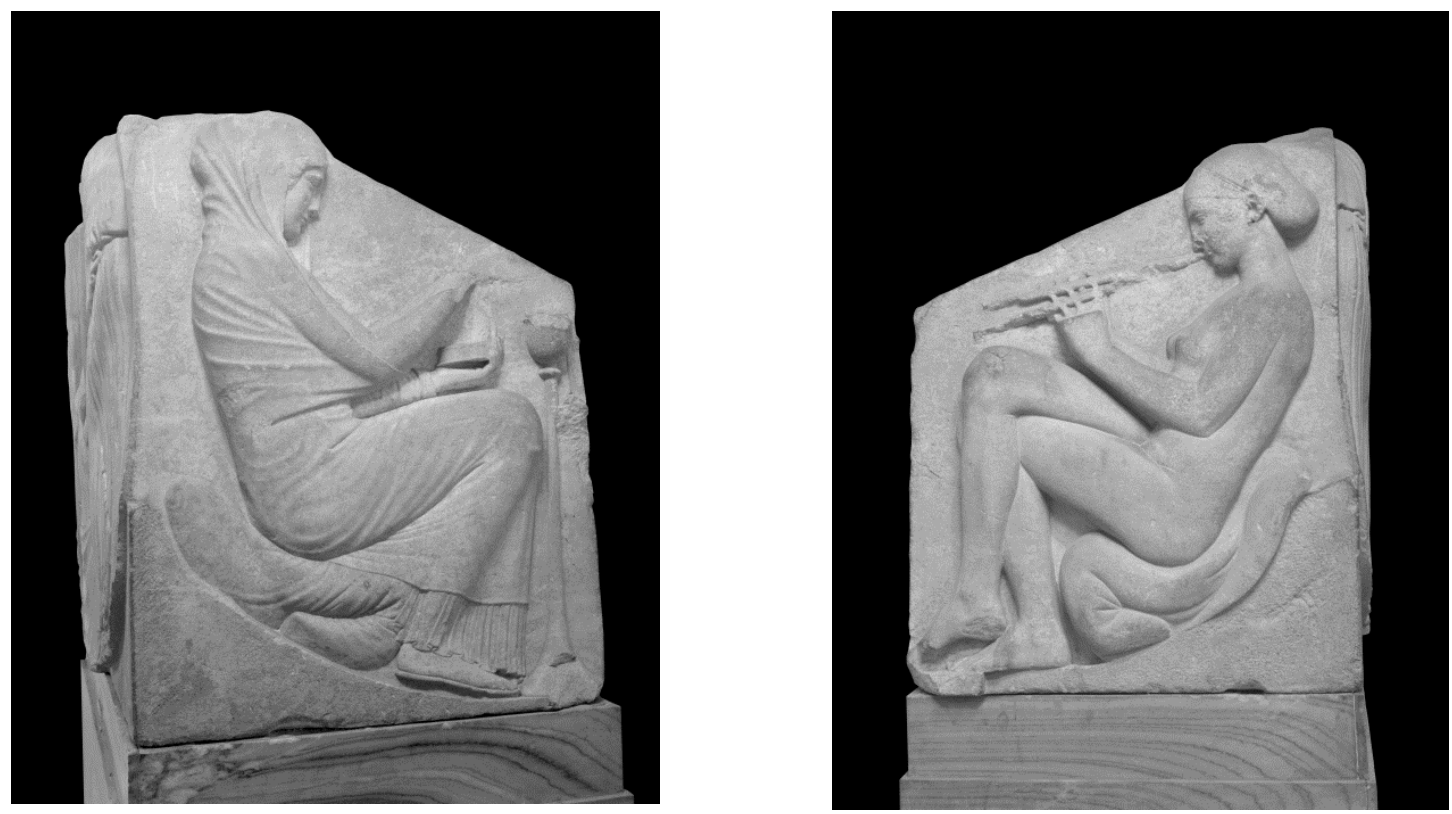

FIG. 2 a-b - The Ludovisi “throne”, flanks. Rome, Palazzo Altemps. Photo: Deutsches Archaeologisches Institut. 


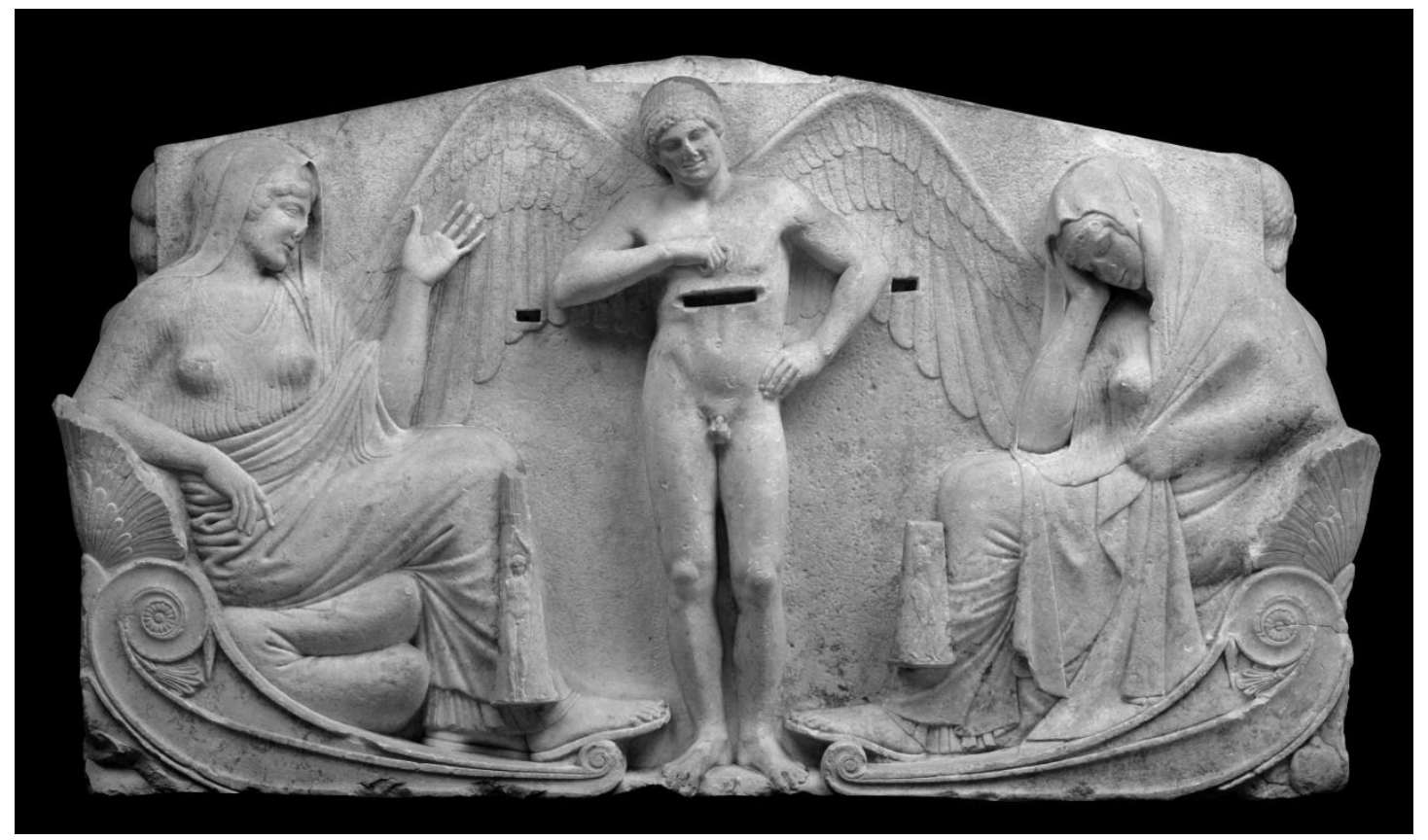

FIG. 3 - The Boston “throne”, front. Boston, Museum of Fine Arts. Photo: Museum.
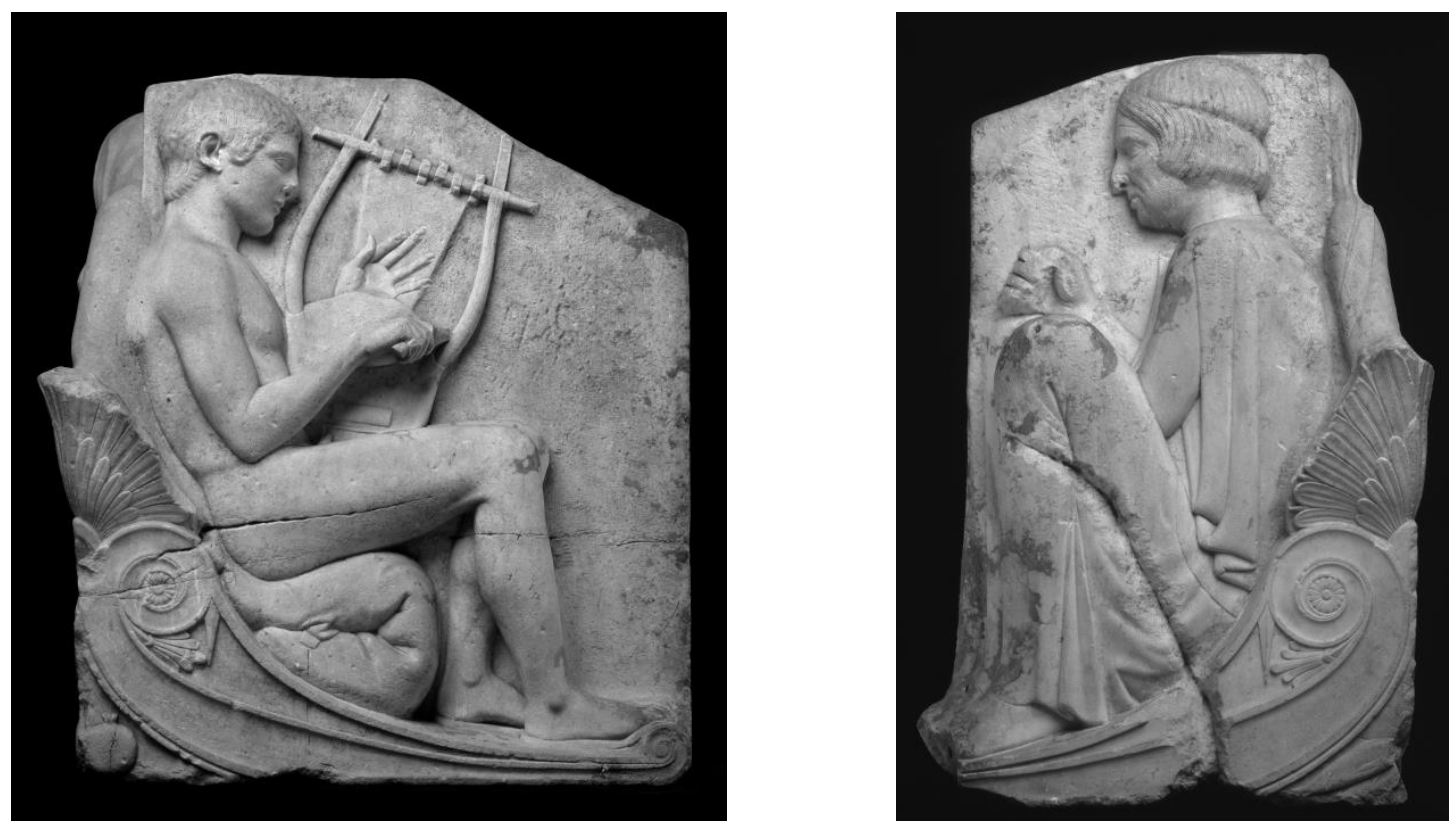

FIG. 4 a-b - The Boston "throne", flanks. Boston, Museum of Fine Arts. Photo: Museum. 
However, the Boston "throne" still had many defenders, though their number diminished somewhat after the attacks on it delivered by M. Guarducci in the nineteen eighties. ${ }^{5}$ At a conference in 1996, when the two "thrones" appeared together at an exhibition in Venice, practically every imaginable argument for or against their authenticity was proffered. ${ }^{6}$ After that, the monuments have periodically surfaced in scholarly debates. In 2003 V. M. Soleti summed up most of the opinions given on the "thrones" up to that year. ${ }^{7}$

More recently some original ideas were presented by A. Bottini and M. Torelli in 2011. The former reconstructed the Ludovisi "throne" as a rectangular monument which was cut down to its present shape when it was removed to Rome. ${ }^{8}$ Torelli compared Bottini's reconstructed monument to the so-called Tribune in Eshmoun in present-day Lebanon, suggesting that the two had a similar function. ${ }^{9}$ He furthermore re-launched E. Petersen's ideas from 1892 that the Ludovisi "throne" originally stood in the temple for Aphrodite in Eryx in Sicily, and that it in its re-cut shape had served as a throne for an acrolith statue.

In an article in the Italian periodical Archeo in May 2016 M. Barbanera brought the two "thrones" up again. ${ }^{10}$ His article was followed by a debate in the Palazzo Altemps in Rome, where the Ludovisi "throne" is exhibited. For the occasion a cast of the Boston "throne" was placed beside it. This cast remained for some time in the museum, and one could therefore study the two monuments together.

Like most scholars, Barbanera attacked the Boston "throne" and spared the Ludovisi "throne". Other scholars have declared that the two monuments belong together, and that one cannot condemn one without condemning the other. ${ }^{11}$ Personally, I agree with the latter. There are too many elements which connect the "thrones": first and foremost their material, Thasian marble. The use of this marble is generally associated with the Imperial period. It is not securely attested in Italy as early as the $5^{\text {th }}$ century BC. Of course, the Ludovisi "throne" could be the exception to this rule, but it would be too much of a coincidence if a modern forger should hit upon the same type of marble for the Boston "throne". Furthermore, mention should be made of the peculiar cushions on which the lateral figures on both "thrones" are seated, the strapless sandals on some of the figures, the hairdo and the hijab-like headdress of the woman offering incense on the right lateral panel of the Ludovisi "throne" and the similar coiffure and head-covering of the two women on the front of the Boston "throne".

I shall here not list all the anatomical "faults" displayed by the figures on the two "thrones", ${ }^{12}$ nor discuss whether the over-long (or too short) arms of the women flanking the central figure on the Ludovisi throne are "faulty" 13 or "lyrical". To one scholar the anatomical imperfections on the Ludovisi "throne" are regarded as the clear sign of a forger's hand, to another, they prove the authenticity of the piece. When A. von Gerkan maintained that the

\footnotetext{
${ }^{5}$ Guarducci 1980, 1985, 1987.

${ }^{6}$ AaVv, Il Trono Ludovisi e il Trono di Boston, Venezia 1997.

${ }^{7}$ Soleti 2003.

${ }^{8}$ Bottini 2011.

${ }^{9}$ Torrelli 2011.

${ }^{10}$ Barbanera 2016.

${ }^{11}$ Eisenberg 1997, 19, 33; Andreae 1997, 73.

${ }^{12}$ For those see especially Eisenberg 1997.

${ }^{13}$ Eisenberg 1997, 20 (faulty); Orlandini 1997, 67 (lyrical). On Studniczka's reconstruction of the Ludovisi "throne" the arms of "Aphrodite" become far too long (Studniczka 1911, 77, Fig. 17).
} 
Boston "throne" had been deliberately mutilated and was therefore a forgery, ${ }^{14} \mathrm{R}$. Carpenter agreed with regard to the mutilations, but drew a completely different conclusion from von Gerkan's observations. ${ }^{15}$ The study of the "thrones" is an act of faith. You believe that they (or one of them) are genuine, or you believe that they are forgeries, and you interpret your observations accordingly. This also means that the same questions are posed and the same answers are given.

Most of the relevant observations on the "thrones" (apart from those of a technical nature) were already made by the first publishers Visconti, Petersen and especially Studniczka. ${ }^{16}$ Other scholars have made the same observations later, perhaps without having read Studniczka's fundamental article. I shall here take up only a few of the controversial themes.

Starting with the motif on the front of the Ludovisi "throne", it is now mostly considered to be the birth of Aphrodite. Persephone rising from the earth has also been suggested. ${ }^{17}$ The possibility of a birth scene was also discussed, generally with a negative conclusion. R. Carpenter had an original view. He believed that Hera-Eleythia was represented in the position of a woman giving birth, but with no child being born. ${ }^{18} \mathrm{~A}$ more energetic action from the flanking women is to be expected if this were really a birth scene.

However, Carpenter is right in emphasizing the downward movement of the group. The attendants of the central woman are not lifting her, merely supporting (Carpenter speaks of "a sagging equilibrium"). ${ }^{19}$ In her book on the Ludovisi and Boston "thrones" E. Simon agrees that it would be impossible for the flanking figures to lift, but according to her, only a light support is needed, because the central figure (Aphrodite, in her opinion) is rising by her own force. $^{20}$

Already Studniczka noticed that the closest parallel to the front of the Ludovisi "throne" is furnished by a fourth-century Etruscan mirror showing the dying Amazon Penthesileia. ${ }^{21}$ She is sinking to her knees and held under the armpits by Odysseus and Diomedes. Carpenter remarked on the importance of this mirror, and deduced that like it, the Ludovisi "throne" derived from a model of circular shape. ${ }^{22}$ It did evidently not occur to him that the mirror (or a similar artefact) could have been a model for the throne, and that the latter therefore could not be a fifth century work. More than fifty years later J. M. Eisenberg made the same observations as Carpenter, but concluded that the Ludovisi "throne" must be a forgery, and that the mirror had served as a model. ${ }^{23}$

I shall here add a curious parallel to the motif of a passive figure held under the armpits by two attendants. It is a vase by Douris (ca. 480 BC) in Fort Worth, Kimbell Museum. ${ }^{24}$ Like

\footnotetext{
${ }^{14}$ Von Gerkan 1929.

${ }^{15}$ Carpenter 1941, 41-51, especially note 1.

${ }^{16}$ Visconti 1887; Petersen 1992; Studniczka 1911.

${ }^{17}$ For the various opinions on the subject see Soleti 2003, 101-103.

${ }^{18}$ Carpenter 1941, 54-61.

${ }^{19}$ Carpenter 1941, 53.

${ }^{20}$ Simon 1959, 10.

${ }^{21}$ Studniczka 1911, 106, Fig. 35.

${ }^{22}$ Carpenter 1941, 53-54.

${ }^{23}$ Eisenberg 1997, 19-20, Figs. 2-3 b.

${ }^{24}$ Leipen et al. 1984, 16, no. 12; LIMC VI, 312, no. 43; Buitron-Oliver 1995, 34, 80, no. 121, Pl. 73; Neer 2002, 56-60, Fig. 24.
} 
the Ludovisi "throne" it shows two women, the left one wearing a peplos and the right one a chiton with the contour of the legs showing through the fabric. They are bending over a torso, in this case male. The torso is held under the armpits. Its head is turned toward one of the women, and its arms are outstretched. However, below the waist there is nothing, only entrails descending from the body. This grisly scene represents the dead Pentheus being torn to pieces by two maenads. His head, which they hold by the hair, is probably going to be ripped off. If one imagines a cloth covering Pentheus' entrails and his missing lower body, there is a certain resemblance to the Ludovisi "throne". Indeed, like Pentheus, Aphrodite seems to lack her lower body. There is no trace of hips or thighs outlined under the fabric. As remarked by Studniczka, many parallels to the Ludovisi "throne" are furnished by Attic vase paintings. ${ }^{25}$ Has the creator of the "throne" seen something similar to the Douris kylix, and if so, why has he changed the context completely $?^{26}$ If the Ludovisi "throne" represents a birth, it is curious that its only parallels in ancient art show dead or dying persons held up under the armpits.

Of the two women flanking Aphrodite on the Ludovisi "throne", the one on the left wears a peplos with a rather short overfold, the folds of which sometimes end in a loop at the bottom (FIG. 1). The folds at the back do not fall vertically, but form a bend (FIG. 1). When a woman wearing an unbelted peplos bends forward, the overfold would normally fall vertically, but on the Ludovisi "throne" it follows the contour of the body, as if it were soaking wet. Moreover, the overfold forms pseudo-sleeves, which can clearly be seen in the fabric falling over Aphrodite's right arm. This effect is typical of the chiton, where the edges of the fabric are fastened with pins or buttons, but impossible in a peplos. Studniczka noticed these "impossible" pseudo-sleeves, but he regarded them as a sign of "Eine reizvolle Naivität". ${ }^{27}$ Eisenberg, who made the same observation, saw the misunderstood sleeves as the work of a forger's hand. ${ }^{28}$

With regard to the lower part of the body, the wet-look effect continues, the fabric following the outline of the thigh. One of the folds covering the thigh is tear-drop shaped, although it is supposed to fall vertically down to the feet. Even stranger is the effect of the fabric falling over the left (inner) calf, where it forms a fold following the outline of the leg (FIG. 1). This is impossible, and it is also impossible that one should be able to see the left leg through the fabric of a peplos, which is commonly a heavy woolen garment. The result of this is that the left leg appears to be on the same plane as the right one. The same effect is seen in the right calf of the chiton-clad woman on the right. Her dress features the same wet-look effect as that of the left woman, but in this case it is more natural, since the chiton is made of a thin material. The inspiration for these oddities is probably Late Archaic and Early Classical Athenian vase paintings, where the contours of women's legs are seen through a thin fabric. In relief sculpture of these periods similar effects are never attempted. Studniczka was aware

\footnotetext{
${ }^{25}$ Studniczka 1911, 186.

${ }^{26}$ The good state of preservation of this kylix suggests that it was found in an Etruscan chamber tomb. One cannot exclude that this very kylix was in the art market during the 1880 'ies, and then disappeared into a private collection. However, since it was published for the first time in 1984 with no provenance given, chances are greater that it is a more recent find which has never been notified to the local soprintendenza.

${ }^{27}$ Studniczka 1911, 173-174.

${ }^{28}$ Eisenberg 1997, 21.
} 
Fig. 5 - So-called Penelope. Vatican Museums. Photo: Deutsches Archäologisches Institut.

of the impossiblity of these folds, but he remarked: "Höher als die sachliche Richtigkeit stand eben dem Künstler der Linienaufbau seiner Komposition, für den diese aufsteigenden Schrägen unentbehrlich sind." 29 In the fourth edition of Helbig's guide, H.von Steuben has a less positive view of these folds. He regards them as errors, but the errors of a fifth century artist. ${ }^{30}$ More skeptical persons, including myself, are left with the impression that the man who carved the Ludovisi "throne", had never seen a peplos or a chiton worn by women in real life.

Also the seated woman on the right flank of the Ludovisi "throne" shows certain anomalies (FIG. 2 a). She is wearing a chiton under a himation. The fabric of the chiton is extremely thin on the upper part of the body (it is barely visible in photographs), while it is much more substantial where it emerges at the bottom. The woman has a double headdress like the two women on the Boston "throne", a feature which is only paralleled there and in the so-called Penelope type (FIG. 5). ${ }^{31}$ The edge of the himation divides the right arm of the woman lengthwise. The taut fabric of the himation has no relevance to the rest of the garment, which envelops the upper body in horizontal folds. The left arm is encased in the himation, which is wrapped around it so tightly that it looks like a sleeve. The sculptor evidently had no real understanding of how the folds of a himation should fall when the garment envelops the body.

The flute-playing woman on the opposite side of the "throne" is nude, so in her case, there is nothing to be said about draperies and fabrics (FIG. 2 b). Her cross-legged position has been criticized, however. Already her publisher Luciano Visconti was a little dissatisfied with it. According to him, she is "benissimo ideata, e disegnata con franchezza e con maestria

\footnotetext{
${ }^{29}$ Studniczka 1911, 176.

${ }^{30}$ Helbig $^{4}$ III, 261 (under no. 2340).

${ }^{31}$ For this type see especially Studniczka 1988; Amelung 1903-1908, II, 439-440, no. 26, Pl. 47; Paribeni 1953, 47-48, no. 78; Ridgway 1970, 101-105; Giuliano 1995, 81-84, S. 78.
} 
grande, salvo, forse, l'attaccatura della coscia destra". ${ }^{32}$ Also Studniczka was aware that the position of the woman's legs is "faulty", and remarked that her left knee seems to grow from her right leg. ${ }^{33} \mathrm{He}$ points out other errors as well, but again, he does not attribute them to a forger.

Do these oddities mean that the Ludovisi and Boston "thrones" are forgeries? Not necessarily, for "oddities" often recur in retrospective Roman works. I shall in the following not look for parallels in Classical Greek art, but rather for Roman ones.

If one starts with Aphrodite on the Ludovisi "throne", one does not have to go back to Greek vase paintings to find parallels to her. This trim, narrow-hipped, boyish body with the breasts far apart and the navel showing through the thin fabric, recur in the severizing "Electra" from a Pasitelan group of a man and woman (in my opinion Venus and Adonis) found in the macellum in Puteoli. ${ }^{34}$ The Esquiline Venus, which was found in 1874, has the same boyish body. ${ }^{35}$ A replica in the Louvre testifies to the popularity of the type. ${ }^{36}$ Statues like these may well have inspired the creator of the Ludovisi "throne", who only needed to shift the breasts a little (on "Electra" and Venus they sit more or less in the armpits) and cover the body with thin, rippling folds. Though the fabric adheres closely to the skin, it nevertheless forms two flat strips framing the torso. This flattening of the relief where the garments do not touch the body, is typical of Archaizing sculpture. ${ }^{37}$

The same effect (that is, the flattening of the relief) is seen in the retrospective Chiaromonti relief in the Vatican Museums, which represents the three Graces (FIG. 6) ${ }^{38}$. This relief shares other features with the Ludovisi "throne": the edges of the overfold of the peplos "glued" to the arms, giving the effect of pseudo-sleeves, the folds ending in a loop, as can be seen between the feet of the left Grace, and last but not least the strapless sandals, which recur both on the Ludovisi and Boston thrones. Contrary to what J. M. Eisenberg has said, ${ }^{39}$ the strapless sandals are in themselves not a sign of a forgery, for they recur on the sculptures from the Temple of Zeus in Olympia, various Archaic and Classical funerary reliefs from the

\footnotetext{
${ }^{32}$ Visconti 1987, 270.

${ }^{33}$ Studniczka 1911, 148.

${ }^{34}$ BrBr 306; Borda 1953, 43-54, Figs. 7-9; Simon 1987, 294-298, Fig. 4; Ridgway 1970, 135-137, Fig. 175; Moreno 1994, II, 746, 749, Fig. 912. The reason why I think that the group represents Venus and Adonis, is that a hunter like Adonis would be suitable for a macellum. Roman hunters, not only professionals, but also "amateurs" who had surplus meat, used to sell it in the macella. As for "Electra", the fact that she is placed on a higher level than her partner (on a piece of rocky ground), indicates that she is more important than him, and her dress, which is an adaption of the Aphrodite Napoli/Frejus-type, suggests that this goddess is meant.

${ }^{35}$ Stuart Jones 1926, 211-212, no. 4, P1. 80; Carpenter 1941, 30-35, Pls. 13-14; Helbig ${ }^{4}$ II, 1484 (text: K. Parlasca); Ridgway 1970, 133, Figs. 49-50; Häuber 1986a, 79-82, Pl. 9, Figs. 49-50; Moreno 1994, II, 747-752, Figs. 915, 917, 918, 920, 926.

${ }^{36}$ Charbonneaux 1963, 34, no. 3436; Häuber 1986a, 81, Fig. 52; Moreno 1994, II, 750, Figs. 914, 916.

${ }^{37}$ Ridgway 1977, 305.

${ }^{38}$ Amelung 1903-1908, I, 546-548, no. 360, Pl. 58; Fuchs 1959, 59-63, Pl.12 b; Helbig ${ }^{4}$ I, 351 (text W. Fuchs); Ridgway 1970, 114-121, Fig. 153; Ridgway 2002, 232, 251 with n. 36, Pls. 107-108; AaVv 1995, vol. 2, 428-429, vol. 3, 40.

${ }^{39}$ Eisenberg 1997, $25 \mathrm{~m}$.
} 
FIG. 6 - Relief with the Three Graces, Vatican Museums. Photo: Deutsches Archäologisches Institut.

Ionian area, a fifth-century relief from Thasos in the Archaeological Museum in Istanbul and the seated goddess from Taranto in Berlin, to mention a few examples. $^{40}$

A sculptural type which may have inspired the sculptor of the Ludovisi "throne" is the "Penelope" mentioned above. Not only the head-covering of the woman on the right flank of the throne, but the idea of the crossed legs of the nude flute-player on the left

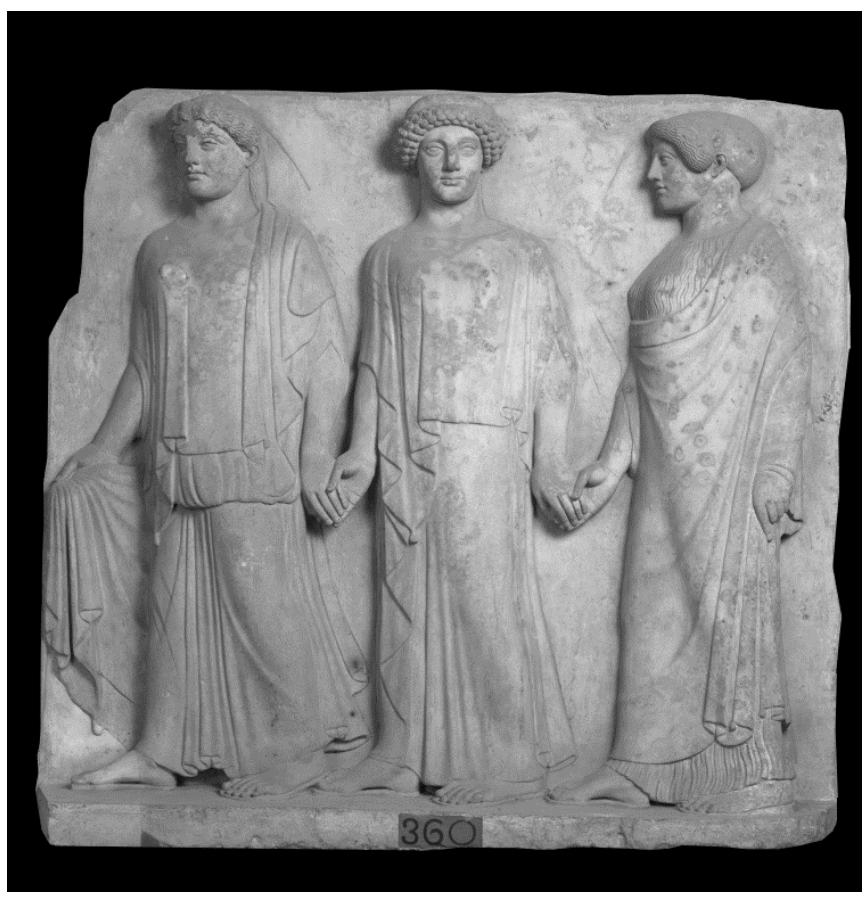
flank could also derive from the Penelope type. A variant of Penelope in the Vatican Museums shows locks of hair merging with the thin folds of the chiton (FIG. 5), and a similar effect is seen on Aphrodite on the Ludovisi throne, where one lock of hair descends on the right shoulder.

Another peculiar feature of Aphrodite's hair is how the strands part to expose the upper part of the ear. To this there is only one parallel in Ancient art, the so-called Humphry Ward head in the Louvre. ${ }^{41}$ Originally thought to be a Greek original, ${ }^{42}$ this head has lost much of its luster. At best it is a Roman work, but hardly a copy of a Greek head. The incoherent and clumsy way the hair is rendered in profile suggests that the sculptor had no model, but tried to render the locks as best he could. Already E. Sellers ${ }^{43}$ pointed out the resemblance between the Humphry Ward head and Aphrodite on the Ludovisi "throne". Alain Pasquier was right when he remarked that the resemblance was "étroit, presque troublant", for in the course of more than hundred years, no other parallel has been found. ${ }^{44}$

If one attempts a dating according to the latest features of the Ludovisi "throne", one arrives at a Roman date, not a fifth-century Greek one. This is even truer with regard to the Boston "throne". On this monument hardly a feature has been free from attack. I shall there-

\footnotetext{
${ }^{40}$ Olympia: Ashmole and Yalouris 1967, Figs. 14, 18, 81; Ionian funerary reliefs: Pfuhl and Möbius 1977, no. 30, Pl. 8, no. 43, Pl. 11, nos. 46, 49, Pl. 12, no. 66, Pl.17; relief from Thasos: Ridgway 1970, 46, Figs. 62-65; goddess from Taranto: Blümel 1963, 29-33, no. 21, Figs. 55-59; Langlotz 1963, 18, 69, pls. 50-51; Ridgway 1970, 93-94, Fig. 125.

${ }^{41}$ Sellers 1894, Figs. 1-2, P1. V; Hamiaux 1992, 266-267, no. 294; Pasquier 1997, 54, Figs. 2-4; Ridgway 2002 , 242 (she seems to regard the head as a classicizing work).

${ }^{42}$ Sellers 1894, 199.

${ }^{43}$ Sellers 1894, 199, 202.

${ }^{44}$ Pasquier 1997, 54.
} 


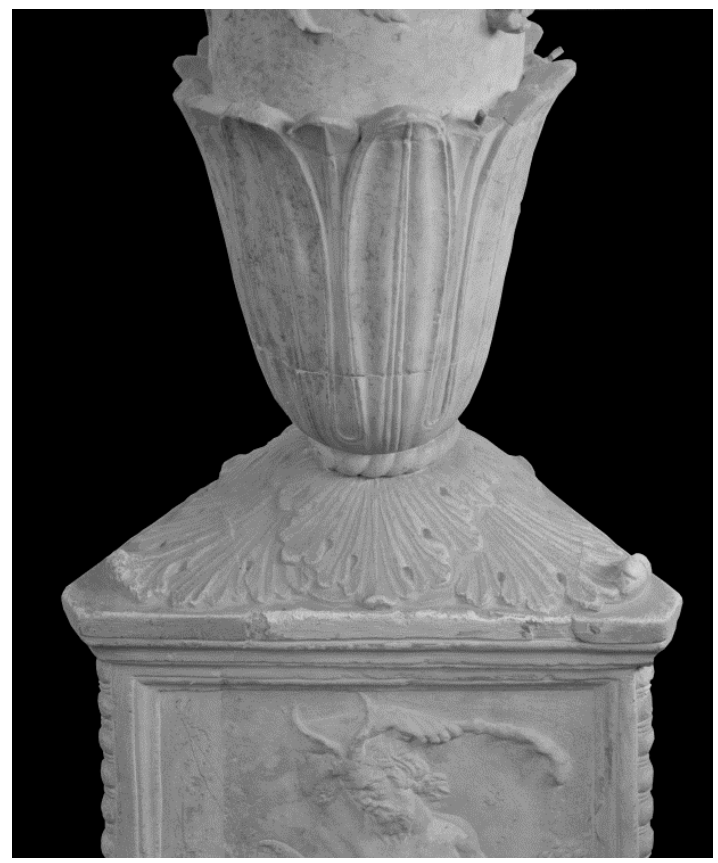

FIG. 7 - Candelabrum, detail. Rome, Musei Capitolini. Photo: Deutsches Archäologisches Institut.

fore concentrate on the decorative elements, the volutes and the corner palmettes, which have been the subject of less interest than the figures. In more recent times F. Baroni and L. Alscher ${ }^{45}$ have analyzed them. Compared to the Ludovisi "throne" the decorative elements on the Boston "throne" make it seem over-decorated, because the corresponding spaces on the Ludovisi "throne" are blank, only worked over with a toothed claw. However, it is clear that there were plans to decorate these areas also. Either the decorations have been removed in later times, or, more likely, they were for some reason never put in place.

On the Boston "throne" all the figures except the one in the middle of the front (the socalled Eros) are seated on volutes ending in palmettes. For the rosette in the eye of the corner volute a Late Archaic acroterion from Miletus has been used for comparison. ${ }^{46}$ Though the general structure may be compared, the details differ. Augustan art furnishes better parallels. The rosette in the eyes of the volutes, an Archaic feature rarely found in later Greek decorative sculpture, was resumed in the in the decorative apparatus on Augustan altars. ${ }^{47}$ The closest parallels to the corner palmettes on the Boston throne are furnished by Roman marble candelabra and other decorative sculpture of the Augustan period, for instance a candelabrum and a basin in the Vatican Museums, ${ }^{48}$ and a candelabrum in the Capitoline Museums. ${ }^{49}$ (FIG. 7) The smaller palmettes which emerge from the inner part of the volutes resemble those decorating the aedicula capitals from the cella of the Apollo Sosianus temple in Rome. ${ }^{50}$ Mention should also be made of two relief panels from the Horti Sallustiani, made in the same workshop as the Apollo Sosianus temple. ${ }^{51}$ The palmettes emerging from the foliage are very close to the palmettes on the flanks of the Boston "throne" (FIG. 8).

\footnotetext{
${ }^{45}$ Baroni 1961, 32-33; Alscher 1963, 52-54.

${ }^{46}$ Alscher 1963, Fig. 49; Herrmann 1997, 16-17, Fig. 10.

${ }^{47}$ The most famous example is the Ara Pacis: Moretti 1948, 182-183, Figs. 144-145, Pls. 34-34; Galinsky 1996, 145, Fig. 63. For smaller altars see Zanker 1987, 137, Fig. 108, 303, Fig. 238, 322, Fig. 256; Lott 2004, 143, Fig. 13 a, d, 145 , Fig. $14 \mathrm{a}, \mathrm{d}$.

${ }^{48}$ Candelabrum: Lippold 1956, 238, 548, cat. 17, Pl. 128; Cain 1985, 188-189, cat. 105, Pls. 66.4, 67.3, 83.2; Spinola 2004, 231-232, cat. 17, Fig. 25. Basin: Lippold 1956, 57, (G.d.Cand. 106), Pl. 22; Spinola 2004, 38-39, cat. 13, Fig. 7b.

${ }^{49}$ Stuart Jones 1926, 143, cat. 24, Pl. 51; Cain 1985, 176-177, no. 77, Pl. 83.3.

${ }^{50}$ Viscogliosi 1996, 94-96, Figs. 116-122.

${ }^{51}$ Viscogliosi 1996, 136-137, Figs. 163-164b; Talamo 1998, 157-166, Figs. 27-31; Cima and Talamo 2008, 127-128, Figs. 19-20.
} 
FIG. 8 - Decorative panel from the Horti Sallustiani, detail. Rome, Musei Capitolini, centrale Montemartini. Photo: Karina Berg.

FIG. 9 - Candelabrum, detail. Rome, Musei Capitolini. Photo: Deutsches Archäologisches Institut.

Decorative elements in Roman sculpture offer parallels for other features on the Boston "throne" as well: the inwardpointing "spikes" emerging from the volutes recur among the decorations on Augustan marble candelabra. $^{52}$ (FIG. 9) Similar "spikes" decorate Roman fulcra in metal and ivory. ${ }^{53}$ It is probable that the sculptor responsible for the Boston "throne" drew inspiration from decorations on furniture, not only beds, but chairs as well. Parallels to the volutes on the Boston "throne" are found on Roman thrones with solid sides. As most of the preserved examples serve as seats for portrait statues copied from Greek originals, it is impossible to determine if the volu-
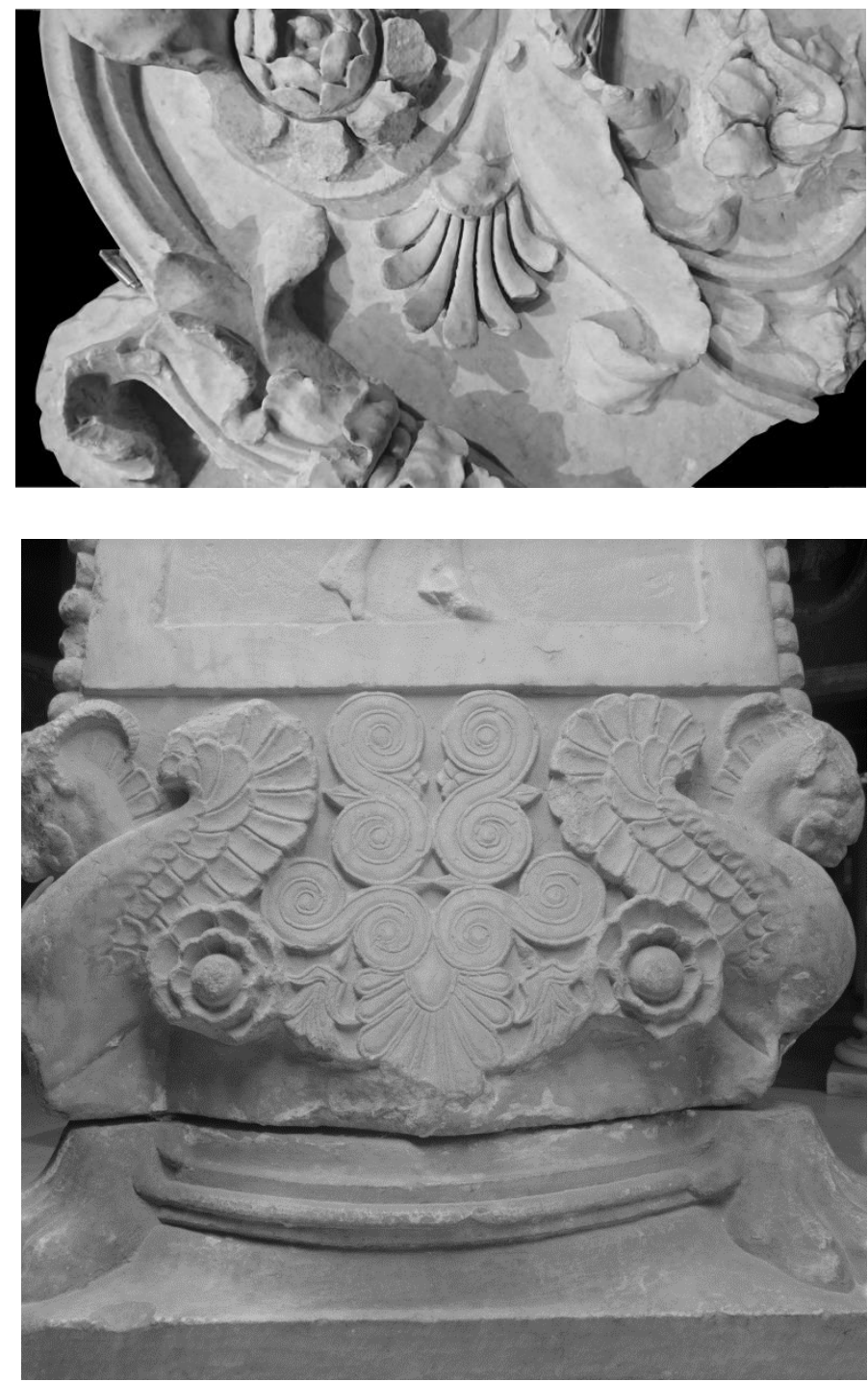
tes were inspired from Greek furniture or if they were added by the Roman copyists.

A Roman example of a throne with solid sides decorated with volutes is furnished by a double-sided relief which from its inscription can be dated to about the middle of the first century BC. ${ }^{54}$ One side copies Demeter from the so-called Great Eleusinian relief, while the other side, which does not render a known model, shows a person seated on a hybrid throne. Along its side runs a fillet ending in a volute. Still closer to the Boston "throne" is the throne of Dionysus on a relief built into the Roman stage of the Theatre of Dionysus in Athens. ${ }^{55}$

\footnotetext{
${ }^{52}$ Cain 1985, Pls. 9-14, 16.5, 17. The models are Hellenistic, as demonstrated by the candelabra from the Mahdia wreck (Cain 1985, 192-193, cat. 115, Pl. 16.3).

${ }^{53}$ Faust 1989, Pls. 20: 1-2, 21: 2, 22: 1-2, 24: 2, 25: 1-2, 26: 1, 27: 1-2, 29: 3. Cosentino et al. 2001, 244.

${ }^{54}$ Bottini 2005, 152-155, cat. 19 (text: E. La Rocca).

${ }^{55}$ Bieber 1961a, 18, Fig. 55; Richter 1966, Fig. 486.
} 
There one sees both the rosette in the eye of the volute and the small palmette spouting from between the volute and the fillet which runs along the seat.

It has been remarked that in ancient sculpture, it is highly unusual to let the ornament form part of the figural composition to the extent that the persons sit or recline on them, as they do on the Boston "throne". ${ }^{56}$ However, if the ornaments are inspired from furniture decorations, this choice becomes more understandable. Furthermore, it should be remarked that figures seated or standing on consoles, capitals and scrolls are staple features in Roman wall painting. If the Boston "throne" is a work of the Augustan period, the sculptor would have good models in contemporary wall-paintings and decorative work such as candelabra and furniture.

The four seated figures on the Boston "throne" are all placed above the decorative volutes covering the corners of the monument (FIG. 3). Of the two women on the front panel, the right one is clearly indebted to the Penelope type. Both women are shown with their legs in profile and their chest more or less frontally. The left woman is seated on a cushion, while the right one seems to float in the air. There is room for a cushion beneath her, but instead the space is filled with draperies, far too many for the himation she is wearing (has she draped a shawl across her lap?). Stylistically there is a generation between the heads of the two women. The one of the right has a Classical face with rounded cheeks and a rather small chin, while the one on the left has an Early Severe face with heavy chin and certain lingering Archaic features such as the almond-shaped eyes and the slightly upturned lips giving the impression of a smile. Such differences in the same relief make one suspect that this is a retrospective work.

The young nude lyre player on the right panel of the Boston "throne" has a small, erected penis, which is out of place in a musician (FIG. 4 a). Jerome M. Eisenberg wondered how many had noticed this detail. ${ }^{57}$ It certainly did not escape Studniczka's eye. He remarked: "Das Bedürfnis nach Vollständigkeit gebietet, vom Schamglied wenigsten die Spitze zu zeigen". ${ }^{8}$ Other scholars probably saw it, but preferred not to mention it. The youth must be thought of as a pendant to the nude flute player on the Ludovisi "throne". Both have been criticized for the way they manipulate their instruments, in particular by J. M. Eisenberg and L. Vlad Borrelli. ${ }^{59}$ The former pointed out that the flutist's wrists should have been bent back, as they normally are on Greek vase-paintings. He also misses the distended cheeks and the phorbeia, the mouth band strapped around the face of Greek flute players. However, on Roman Arretine ware, where flutists are often represented, their wrists may be only slightly bent, and in some cases even bent forward. ${ }^{60}$ For the Roman artist, the correct flexing of the wrists was evidently less important than it was for his Greek colleague. The phorbeia does not seem to have been important either, as many Roman representations of flute players lack it. Again one sees that the Ludovisi "throne" is closer to Roman than to Greek models.

The left panel on the Boston "throne" is filled by an old woman (FIG. 4 b). She does not sit on the volute, but rather squeezes into the space behind it, as there is not room for her buttocks. This figure has come in for a great deal of criticism from L. Alscher, J. M. Eisenberg

\footnotetext{
${ }^{56}$ Baroni 1961, 31; Alscher 1963, 21 with n. 86; Eisenberg 1997, 28.

${ }^{57}$ Eisenberg 1997, 31, d.

${ }^{58}$ Studniczka 1911, 168.

${ }^{59}$ Borrelli 1993; Eisenberg 1997, 23 m, 24 g.

${ }^{60}$ Porten Palange 2004, Pl. 31, GMre7a; Pl. 33, GMli2a, Pl. 34, GMli3a, GMli5a, GMli5b; Pl. 129, wTMFli7a.
} 
and others. ${ }^{61}$ The squatting Hecuba on a hydria by the Kleophrades painter has been proposed as a model for her. ${ }^{62}$ However, one does not need to go to Greek vase painting to find a source of inspiration. There were models closer to hand for a Roman artist. I am thinking of the squatting old woman attributed to an artist called Myron. ${ }^{63}$ Whether the original is a work of the third or second century B.C. or, as I believe, an eclectic creation of the early first century B.C., is of less importance here. What matters, is that the type was evidently popular. A Roman sculptor may well have seen copies of the anus ebria, or he may have been inspired by small-scale versions of the same motif.

Only the squatting motif may have been taken over from Myron's old woman and her sisters, because they are normally drunk, while the woman on the Boston "throne" looks definitely sober. Her long, horsey face (which made Eisenberg doubt her sex) is probably borrowed from the so-called Lysimache. ${ }^{64}$ This type was long thought to be a portrait of the fifth century B.C., but if H. Berger's combination of the head with a stooping body in Basle is correct, she is no portrait at all, but a genre figure. ${ }^{65}$ If one tries to think away Lysimache's Classicizing coiffure to study only her face, one realizes that it is inspired from male portraiture from the third quarter of the first century B.C. ${ }^{66}$ The sculptor of the Boston "throne" has substituted Lysimache's hair style for a short, bobbed hairdo, reminiscent of the hair worn by grieving women and female slaves in Classical Greek vase painting.

The old woman's cramped position, her missing left arm and other oddities have been commented on by scholars already. These "faults" are mostly due to lack of space, since the left flank of the Boston "throne" is much narrower than the right one. It seems strange that a Greek sculptor (or a Roman one, for that matter) could not gauge the size of the block.

Another feature of the two "thrones" which is un-Greek, is the type of cushion some of the persons sit on. The two musicians may have been inspired from Arretine ware, where flutists and lyre players are frequently seen seated on low stools with the lower part of their bodies covered in draperies. ${ }^{67}$ The sculptors of the two "thrones" have removed both the draperies and the stools, giving the musicians cushions instead. These cushions are very particular, unlike the hard cushions which are covering the furniture in Greek paintings. No wonder Carpenter and Eisenberg took them to be wine sacks. ${ }^{68}$ They are, however, big, fat cushions, the closest parallels to which are to be found on the so-called Warren cup in the British Museum. $^{69}$

This silver cup, which originally belonged to the American collector Ned Warren (who al-

\footnotetext{
${ }^{61}$ Baroni 1961, 28-30; Alscher 1963, 40-43, 48-50; Guarducci 1987, 54; Eisenberg 1997, 29-30.

${ }^{62}$ Eisenberg 1997, 29 a, Fig. 13.

${ }^{63}$ See especially Zanker 1989; Wrede 1991, 168-175; Sande 1995.

${ }^{64}$ Richter 1965, I, 155-156, Figs. 878-881; Richter and Smith 1984, 158-159, Fig. 120; Ridgway 1981, 181, 231-234, Pl. 146.

${ }^{65}$ Berger 1968, 67-70, Pls. 31:1, 33.

${ }^{66}$ Sande 1995, 43.

${ }^{67}$ Porten Palange 2004, Pl. 31, GMre15a, GMre15b, Pl. 34, GMli5a, GMli5b, Pl. 128, wTMFre9a, wTMFre10a, Pl. 129, wTMFli7a.

${ }^{68}$ Carpenter 1941, 41; Eisenberg 1997, 23 n.

${ }^{69}$ See especially Clarke 1993; Clarke 1998, 61-90, Figs. 16-22, Pls. 1-2; Pollini 1999; Williams 2006; Marabini Moevs 2008.
} 


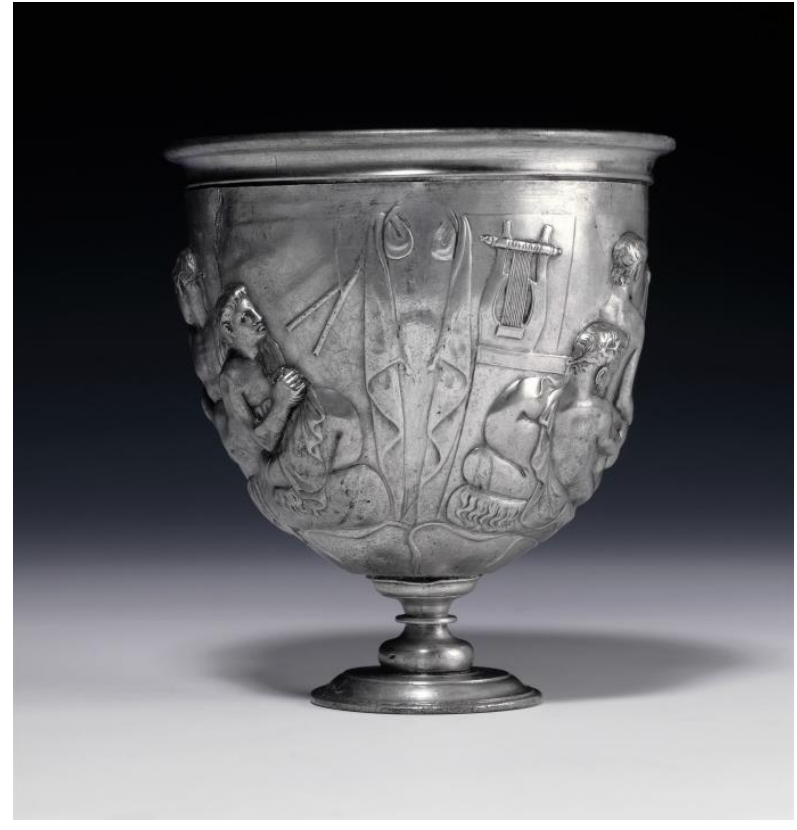

mature man and his companion through a door.

While the scene on side A is a hapax, there are parallels to the scene on side B. It is instructive to see how the master of the Warren cup has altered this scene, which is found in other media such as terracotta (Arretine ware) and cameo glass. ${ }^{70}$

The scene with the man and the boy occurs together with heterosexual symplegmata decorating Roman tableware, seemingly as a willed contrast to the latter. ${ }^{71}$ It should be noted that while the girls in these symplegma scenes all appear to be willing, the boy is not. While his partner has inserted his left hand between the boy's thighs, trying to separate them, the boy grips his arm as if he wants to push it away.

It is often supposed that the decorations on Roman tableware furnished themes for conversations and discussions, and in the context of erotic symplegmata, the boy stands out in contrast to the willing females. Is his partner's advances really unwanted, or is he simply playing coy? Will the man eventually penetrate him, or will he merely fondle him? The boy's apparent unwillingness creates an atmosphere of ambiguity. One gets the impression that the Arretine ware and the cameo glass were made for the average Roman dinner guest: a man who was basically heterosexual, but who did not disdain a pretty boy if he could lay his hands on one.

On the Warren cup there is no room for doubt, the boy - willing or not - is being penetrated by the youth. The active partner has turned his head away from that of the boy. The latter's body has been completely distorted to show the act of penetration. On side A there are also anatomical distortions with a view to show penetration. These distortions are clearly willed, and are not due to the artisan's incomplete understanding of human anatomy. The Warren cup

\footnotetext{
${ }^{70}$ Clarke 1993, 282-285, Figs. 12-14; Clarke 1998, 72-82, Figs. 25-27, Pls. 4-5; Pollini 1999, 28-32, Figs. 10-13; Porten Palange 2004, P1. 123, Sy19a-19d; Williams 2006, Figs. 23-25; Marabini Moevs 2008, 8, Figs. 12-13.

${ }^{71}$ Clarke 1993, 283, Fig. 12; Clarke 1998, 73-75, Fig. 25, Pls. 3-4; Pollini 1999, 31, Fig. 12; Williams 2006, 40-41, Fig. 23, 43, Fig. 25; Porten Palange 2009, Pl. 33, Komb.Per. 40b.
} 
was made for a man who preferred males, and who wanted to show it. The setting is vaguely a Greek never-never land, where one was free to choose one's partners.

When faced with such explicit sex scenes as those on the Warren cup, the spectators' eyes will not normally focus on the bedclothes. But if they do, they will see that here are the parallels to the cushions on the Ludovisi and Boston" thrones". Not only the shape of the cushions, but also the way they form deep folds ending in an "eye", is similar.

The lovers are resting on fabric (cloaks, blankets or both?) which exhibits "eye"-incisions, zig-zag folds and weights. A profusion of folds alternates with almost blank stretches, such as the cloak (?) draped over the left arm of the youth in scene A. This contrast between overdecorated and almost blank spaces recurs on the Boston "throne", especially on the right woman on the frontal panel (the so-called Persephone). Her back is more or less smooth and seems to merge with the background, while there are too many draperies in front. The zig-zag folds and "eye" folds on the Warren cup (FIG. 10) recur in the draperies of "Persephone" and "Aphrodite" respectively, on the frontal panel on the Boston "throne". They are less conspicuous on the Ludovisi "throne", but there, too, one finds incoherent draperies which defy the law of gravity, notably on the woman to the left of Aphrodite.

The cushions, however, constitute the most striking elements. Maria Teresa Marabini Moevs has in her article on the Warren cup illustrated the matrix of an Arretine cup in the Archaeological Museum of Arezzo, where the same type of cushion is shown. The scene is erotic in character, and Marabini Moevs has persuasively connected it with Alexandrian poetry. ${ }^{72}$ The cushions are therefore Hellenistic, and among the many amenities which the Greeks appropriated from Egypt and the Near Orient after the conquests of Alexander the Great. Before that, they appear to have been rather unassuming with regard to bedclothes, as illustrated by a story about Artaxerxes told by Athenaios and Plutarch. ${ }^{73}$ When the king sent Timagoras a couch with bedding, he also sent some slaves to make the bed, because the Greeks did not know how to do it. The many illustrations of beds in Archaic and Classical art, in particular vase painting, show an often thin mattress and hard cushions. ${ }^{74}$

When the Ludovisi and Boston "thrones" are studied together with the Warren cup and decorative Roman sculpture, it results that the date of the two "thrones" cannot be earlier than the late first century $\mathrm{BC}$ or the beginning of the first century $\mathrm{AD}$. This is especially clear in the case of the Boston "throne", but the Ludovisi "throne" is also suspicious. Here I am thinking of the cushions, which link it to the Boston "throne" and the Warren cup, the parallel between the Aphrodite and the Humphry Ward head, the similarity between the flute player's hands and those of Arretine ware, and a general misunderstanding of how the folds of a peplos and a chiton are falling.

It is possible that the Ludovisi and the Boston "thrones" are retrospective works of art from the end of the Republic or the Augustan period, and when I started to study them, it was with a view to present them as such. However, my encounter with the Warren cup has made me reconsider, for the Warren cup has also been regarded as a forgery.

\footnotetext{
${ }^{72}$ Marabini Moevs 2008, 4-5, Fig. 6.

${ }^{73}$ Athenaios, Deipnosophistes II, 48d; Plutarch, Artaxerxes, 22.

${ }^{74}$ See Richter 1966, Figs. 310-340.
} 
Maria Teresa Marabini Moevs has shown that the young "voyeur" on the Warren cup is an interpolated figure from a scene known in Arretine ware. ${ }^{75} \mathrm{He}$ is alerting his mistress that a new lover is waiting outside. This figure is also known through separate punzioni, that is, stamps (genuine and false), and could easily be removed from its original context. It should here be remarked that Ned Warren, the original owner of the cup, collected and traded in Arretine ware and punzioni. For him to see such motifs on a silver cup, would be no surprise since the Arretine ware often drew inspiration from silver ware.

We are now dealing with three artworks of which two have belonged to the same man (Ned Warren), and which have all to a lesser and greater degree been suspected of being forgeries. They are connected with the same names: Wolfgang Helbig, Paul Hartwig, Friedrich Hauser and the art dealers Antonio and Alessandro Jandolo and Francesco Martinetti. During the "building fever" in late $19^{\text {th }}$ century Rome, large numbers of ancient sculpture came to light, and it would be easy to slip in among them the occasional forgery. As the supply of genuine sculptures diminished, more forgeries were introduced. ${ }^{76}$

The Ludovisi "throne" was supposedly found in 1887, on the former property of Prince Rodolfo Boncompagni Ludovisi, who had sold the greater part of his property for development. ${ }^{77}$ One of the results of this sale was the destruction of the famous Ludovisi park, which partly covered the Gardens of Sallust. Naturally one expected to find ancient sculpture during the construction of the new quarters, and these expectations were amply fulfilled. Prince Boncompagni Ludovisi had therefore stipulated that ancient art found on his former property during the construction work, would belong to his family.

The Ludovisi family already owned a large collection of ancient statuary, but since it was part of a family entail, they were not free to sell single pieces of it on the art market. ${ }^{78}$ Those who offered the "throne" to the family, must have told them that it was not part of the entail and could therefore be sold, and that they could keep part of the income from the sale if they pretended that the "throne" came from their property. The monument was included in the Ludovisi collection, but the family must have been aware that it was a forgery. During a visit to the collection, L. Pollak found that the "throne" contained empty wine bottles, a sign of the meagre respect it enjoyed. ${ }^{79}$

Not only the family, but also prospective buyers showed scant regard for the Ludovisi "throne". When it was offered to the Archaeological Museum in Berlin, the director R. Kekule declined the offer. In his opinion it was "archaistic", that is, a retrospective Roman work. Kekule must conceivably have sensed its "un-Greek" character. ${ }^{80}$ The throne was also offered to Count M. Tyszkiewic, who declined to buy it. One does not know exactly when these offers were made, or if the refusals were influenced by the opinion voiced by G. Visconti, who

\footnotetext{
${ }^{75}$ Marabini Moevs 2008, 4-5, Fig. 7.

${ }^{76}$ Barbanera 2016, 31-33.

${ }^{77}$ For the different versions of the discovery and the findspot of the Ludovisi "throne" see Hartswick 2004, 119-121.

${ }^{78}$ Nash 1959, 119; Moltesen 2012, 107.

${ }^{79}$ Pollak and Guldan 1994, 46.

${ }^{80}$ Pollak and Guldan 1994, 46.
} 
published the "throne" in the same year that it was allegedly found. He considered the "throne" to be a Roman retrospective work. ${ }^{81} \mathrm{~S}$. Reinach was of the same opinion. ${ }^{82}$

The Ludovisi "throne" was also offered to C. Jacobsen, the creator of the Ny Carlsberg Glyptotek in Copenhagen. ${ }^{83}$ This offer came late, towards the end of 1891. Jacobsen's agent W. Helbig described the "throne" as a genuine $5^{\text {th }}$ century work, and strongly recommended that Jacobsen bought it. Both Helbig's recommendation and the accompanying photo left Jacobsen indifferent, it seems. He wrote back that that it would be difficult to exhibit a monument which would need light from three sides. It is interesting to note that as long as the Ludovisi "throne" was presented as a work of art without any attempt of offering a stylistic or iconographic interpretation, it did not raise enthusiasm. ${ }^{84}$ As any employee of an advertising agency knows, in order to launch a product successfully, you have to tell a story.

In 1892 E. Petersen published the Ludovisi "throne" again, and he told a fascinating story. He presented the "throne" as an early Classical work of great beauty, without arguing against the sceptic opinions of Visconti and others - they were simply ignored. While Visconti had interpreted the scene on the front of the throne as the depiction of an anonymous adherent of the Eleusian mysteries bathing in the river Ilissos, Petersen presented the same scene as the birth of Aphrodite. He added an exotic touch by suggesting that the "throne" prior to its arrival at Rome had stood in the sanctuary of Aphrodite in Eryx in Sicily. The nude flute player on the left flank he associated with the "sacred prostitution" which had been exercised in that sanctuary. Furthermore Petersen created a link between the "throne" and the Ludovisi collection by suggesting that the "throne" had been used as a real throne for an acrolith statue, the head of which was the so-called Ludovisi acrolith, recorded in the inventory as early as $1733 .^{85}$

Petersen's article made the scholarly world and prospective buyers look at the Ludovisi "throne" with renewed interest. Unfortunately for the persons who wanted to make money out of the "throne", their project backfired. One of the interested parties was the Italian government, which wanted to purchase the Ludovisi collection. Convinced by Petersen that the "throne" was connected with a head which had formed part of the collection for many years, the Commisione delle Belle Arti refused its exportation. The "throne" was purchased by the Italian government together with the collection only in 1901.

The scholarly success and economic failure of the Ludovisi "throne" project made it necessary for the consortium behind it to launch a new candidate, the Boston "throne". If I am right in seeing the palmettes on the decorative reliefs found in the Via Boncompagni area in 1888 as models for the small palmettes on the Boston "throne" (compare FIGS. 4 a-b and 8), work on the latter must have been begun in the late 1880's, probably after the completion of the Ludovisi "throne".

\footnotetext{
${ }^{81}$ Visconti 1887.

${ }^{82}$ Reinach 1888, 76-77.

${ }^{83}$ Moltesen 2012, 107.

${ }^{84}$ As John Marshall, the secretary of Ned Warren, remarked in his report on the purchase of the B oston "throne": "Nobody considered the 'Throne' (that is, the Ludovosi "throne") to be of first rate importance till Petersen's article appeared in 1892" (quoted in Nash 1959, 130).

${ }^{85}$ Petersen1892. For the acrolith see Helbig ${ }^{4}$ III, 2342 (text: W. Fuchs); Guarducci 1985, 14-20; AaVv 2011, $200-201$.
} 
The Boston "throne" was put on the art market in a roundabout and secretive way. Carl Jacobsen was the first prospective buyer to be offered the "throne", not by Helbig, but by P. Hartwig, a German archaeologist based in Rome, who worked as an agent for various European museums. ${ }^{86}$ In a letter to Jacobsen dated the $3^{\text {rd }}$ October 1894 , Hartwig claimed to have forced himself into the storerooms of the art dealers Antonio and Alessandro Jandolo together with his "damaliger intimer Freund" F. Hauser. ${ }^{87}$ There they discovered a marvelous piece of art, a three-partite relief seeming to be a counterpart to the Ludovisi "throne". In his letter Hartwig gives the impression of having discovered the "throne" a few days before writing to Jacobsen, but according to other sources he and Hauser had seen it already in the summer.

Another prospective buyer was the Archaeological Museum in Berlin, represented by its director R. Kekulé. It is remarkable that Jacobsen and Kekulé, who had not been interested in acquiring the Ludovisi "throne", should now be eager to buy the Boston "throne". Kekulé, who visited Rome in January 1896 in order to see the "throne", must have noticed that it was stylistically similar to a monument which he had dismissed a few years earlier as an "archaistic work". It was however said that the German Emperor wanted the Berliner Museum to buy the Boston "throne", which may explain Kekulé's changed attitude. ${ }^{88}$ As for Jacobsen, it may be that he had read Petersen's article and found out that he should have followed Helbig's advice and purchased the Ludovisi "throne", and that he did not want to miss out on a new opportunity.

Hartwig, who together with his friend Hauser had purchased the "Boston" throne from the Jandolo brothers with money placed at their disposal by the art dealer Martinetti, stipulated terms (complete secrecy for one year followed by a period of several years during which the "throne" could not be published) which were difficult for the Berliner Museum to accept. The Berliner Museum for its part, wanted the "throne" to be handed over in Trieste, which was then outside of Italian jurisdiction. Hartwig and his consortium declined this, and in the end Kekulé withdrew. ${ }^{89}$

This should have left the field open to Jacobsen and a third interested party, the American collector N. Warren, represented by his secretary J. Marshall. However, Helbig did his utmost to dissuade Jacobsen from purchasing the "throne". 90 Jacobsen had offered Hartwig 20.000 lire, which was the price agreed with Helbig for the purchase of the Ludovisi "throne". As M. Moltesen remarks, "Jacobsen must have written to Helbig about the offer, but this letter,

\footnotetext{
${ }^{86}$ For the circumstances of the sale see Nash 1959, 115-132; von Gerkan 1960, 151-154; Alscher 1963, 16-19; Guarducci 1987, 56-58; Moltesen 1990; Moltesen 2012, 110-112. The accounts of the proceedings differ in details.

87 "Sein damaliger intimer Freund", is a quotation from Pollak and Guldan 1994, 47. Facsimile of the letter in Moltesen 1990, 37; Moltesen 2012, 111.

${ }^{88}$ According to Nash 1959, 126-127, Hartwig had told the art dealer Martinetti that that the German Emperor took a personal interest in the Boston "throne" and wanted the Berliner Museum to purchase it. One may wonder how the Emperor came to know about the Boston "throne", which was shrouded in secrecy. Somebody must have alerted him, most likely Helbig, who had received him in his home in Rome in 1888, when he was still a crown prince. Helbig may even have introduced him to Martinetti (Guarducci 1980, 479, 491-492). The reason for Helbig's move was probably that he knew about Kekule's negative reaction to the Ludovisi "throne", and feared that he would be equally negative towards its "twin". An Imperial interest in the monument would put pressure on Kekule, and make him bid for a work he may have distrusted personally.

${ }^{89}$ Nash 1959, 125-127.

${ }^{90}$ Moltesen 2012, 110-112; Barbanera 2016, 35.
} 
strangely enough, is missing." been stolen from the Ludovisi family, and when Jacobsen visited Rome in March 1895, Helbig did not even show him the "throne". It is evident that he did not want Jacobsen to buy it. According to Moltesen, "Helbig had already decided that this time Jacobsen was not to be the lucky buyer of the Boston "throne". 92

One reason for Helbig's reluctance may have been that he did not want Jacobsen to know that he was already involved with the sale of the Boston "throne". A third, anonymous person said to be Italian, had now entered the consortium, and both Warren and Marshall believed that this person was Helbig, since the mysterious person's part of the sale was to be paid to him. ${ }^{93}$ Warren was willing to pay more for the "throne" than Jacobsen, and a better sale would mean a larger return to the parties involved.

Behind Helbig's negative attitude towards Jacobsen, who was not even allowed to see the "throne", there may also have been fear of Jacobsen's "discerning eye". 94 Helbig must have known that the Boston "throne" was a forgery, and if he showed it to Jacobsen, the latter might detect details which were out of place in a fifth century monument. One may of course ask why Helbig then offered to Jacobsen another forgery, the notorious Diadumenos. ${ }^{95} \mathrm{M}$. Garducci was of the opinion that Helbig was behind the false Diadumenos. ${ }^{96}$ M. Moltesen argued for Helbig's honesty in the matter, pointing out that he only two years earlier had offered Jacobsen a torso with so many modern restorations that it virtually amounted to a forgery. ${ }^{97}$ Jacobsen immediately detected this, and it seems odd that Helbig should try his luck with a new forgery so soon afterwards. It could well be that Helbig was not such a great connoisseur after all, as L. Pollak noted in his diary, and that he simply believed that the sculpture was ancient. ${ }^{98}$

Meanwhile (January 1896), the Boston "throne" was purchased by Warren and whisked away to England a few days after the completion of the sale. ${ }^{99}$ As remarked by Barbanera, in the Belle Arti it must have been known that the "throne" was a forgery, otherwise the export of the monument would have been much more complicated and time-consuming. ${ }^{100}$ In England the "throne" was placed in a sort of pavilion in Lewes House in Sussex, Warren's home, where it was shown to a select few. ${ }^{101}$ There it remained till 1908, when it was sold to the Museum of Fine Arts in Boston. In 1909 it was put on display in the museum, and in $1911 \mathrm{~F}$.

\footnotetext{
${ }^{91}$ Moltesen 2012, 110. One strongly suspects that Helbig destroyed the letter.

${ }^{92}$ Moltesen 2012, 110.

${ }^{93}$ Nash 1959, 124, 131.

${ }^{94}$ For Jacobsen's "marvellous discerning eye" or "acute eye" see Moltesen 2012, 114, 195. In her opinion, his "eye" let him down when he declared to be disappointed with a statue of a fleeing Niobid from the Gardens of Sallust (Moltesen 2012, 114). According to B. S. Ridgway, however, this statue is not a Classical Greek work, but a Roman one (Ridgway 1981, 58), so perhaps Jacobsen's “eye” was right after all.

${ }^{95}$ For the Diadoumenos see Guarducci 1980, 507-525; Guarducci 1987, 59-60; Moltesen 2012, 190-196.

${ }^{96}$ Guarducci 1980, 50; Guarducci 1987, 507-525.

${ }^{97}$ Moltesen 2012, 189-191, Figs. 162-163.

${ }^{98}$ Moltesen 2012, 153, 154, 195.

${ }^{99}$ Nash 1959, 128, 130.

${ }^{100}$ Barbanera 2016, 38-39.

${ }^{101}$ Nash 1959, 106; Moltesen 2012, 112. Ludwig Pollak, who was among the visitors to Lewis House, admired the Boston "throne" and never doubted its authenticity (Pollak and Guldan 1994, 46-48).
} 


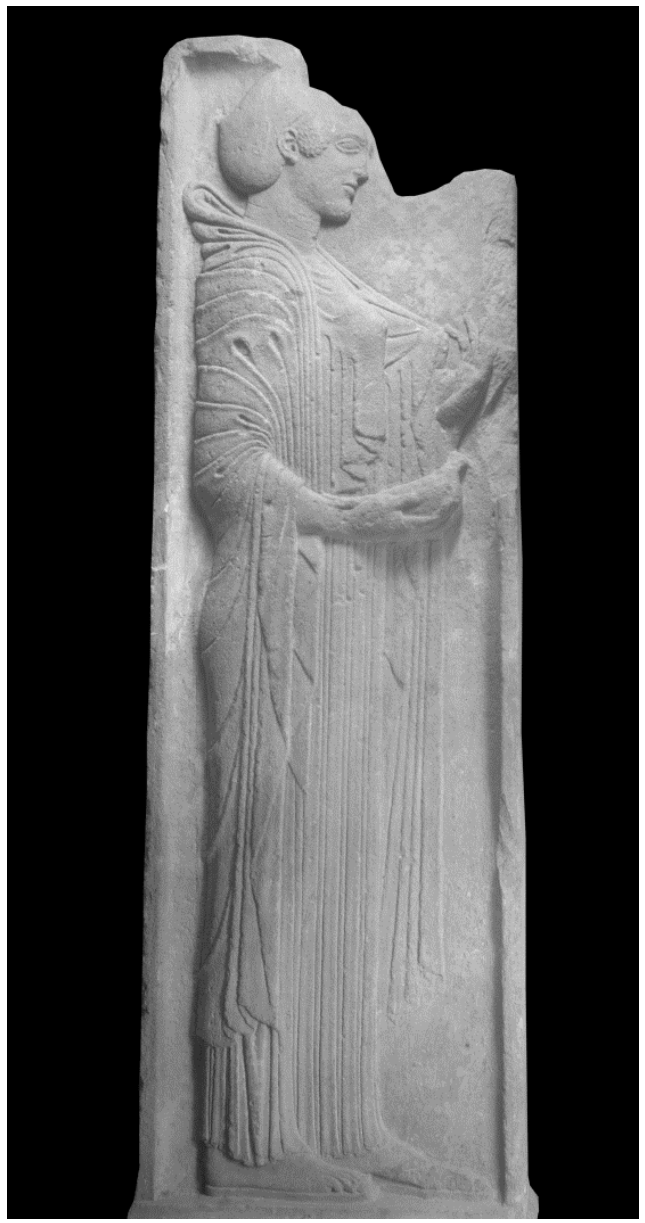

FIG. 11 - Woman with dove, stele from the Esquiline. Rome, Musei Capitolini. Photo: Deutsches Archäologisches Institut.

Studniczka published a long article in the Jahrbuch des Deutschen Archäologischen Instituts, where the "throne" was discussed together with its Ludovisi counterpart, both being hailed as masterpieces of early Classical Greek art.

To explain the lack of solid evidence regarding the discovery of the two "thrones", both were said to have been found during a week-end in the summer. ${ }^{102}$ The Ludovisi "throne" was allegedly found on a Sunday, when no ispettore was about. The Boston "throne" was reported to have been found on a Saturday evening. ${ }^{103}$ The inspectors were not mentioned, but one may assume that they had gone for the day, leaving the "discoverers" the whole Sunday to remove the monument to a safer location.

While the authors of several forgeries have been revealed in the course of time (A. Dossena being the most notorious example), nobody has come forth to claim the authorship of the Ludovisi and Boston "thrones". One of the reasons for this could be that the "thrones" are the result of teamwork - this is at least the impression given by the monuments themselves.

A funerary stele, supposedly found in 1882 in the Horti Lamiani on the Esquiline, now in the Capitoline Museums, seems to be an early effort of the workshop (FIG. 11). ${ }^{104}$ Its stylistic relationship to the Ludovisi "throne" has already been noted. ${ }^{105}$ The material, Thasian marble, is the same. The stele exhibits certain characteristic features from both "thrones", such as the strapless sandals, the folds ending in "eyes" and the long, slender fingers with well-

\footnotetext{
102 Petersen 1892, 32.

${ }^{103}$ This version was told by F. Hauser to L. Curtius. In a letter from 1952 to the director of the Museum of Fine Arts in Boston, Curtius wrote: "Einzelheiten über die Auffindung des Reliefswerks bei den Bauarbeiten auf dem Grund der Villa Ludovisi an einem Samstagabend hat mir genau Friedrich Hauser, der damals mit John Marshall und Mr. Warren arbeitete erzählt...." (Nash 1959, 124, n. 64).

${ }^{104}$ Ghirlandini 1893; Studniczka 1911, 175, Fig. 77; Stuart Jones 1926, 212-213, no. 5, Pl. 80; Helbig ${ }^{4}$ II, 1506 (text: W. Fuchs); Häuber 1986 b, 180-181, Fig. 116; Eisenberg 1997, 25, 28; La Rocca 1997, 37; Bell III, 1998, 303-304, no. 4, Fig. 5; Cima and Talamo 2008, 24, Fig. 15. This relief was allegedly found in the area of the Villa Palombara, "a poca profondità tra le terre di scarico, nel viale principale che condudeva al casino" (Ghirlandini 1893, 145, n. 1). How a relief of this size (h. $1.735 \mathrm{~m}$ ) could land in a spoil heap without being noted by the workmen, is a mystery.

${ }^{105}$ Cima and Talamo 2008, 24.
} 
articulated joints, which recall the hands of the so-called Aphrodite and the lyre-player on the Boston "throne". There is a marked contrast between the naturalism of the hand and the conservative pattern of the draperies. It should also be noted that while the face retains certain archaic features such as the eyes, not yet seen in profile, the neck shows "Venus rings" (even at the back!), which one would not expect in early fifth century Greek sculpture. Like the flutist on the Ludovisi "throne" the Esquiline woman wears a sakkos, in her case a rather odd choice, since this head-covering is normally worn by servants on $5^{\text {th }}$ century funerary stelae.

Like the master(s) of the Ludovisi and Boston "thrones" the sculptor(s) of the Esquiline stele was skillful in creating depth in very low relief. The reason for this was that the forgers used ancient artefacts as material, so that the thickness was already determined. In this case the material may have been a pilaster, the base of which was retained. ${ }^{106}$ As on the "thrones" the breaks are made so as not to be unsightly. On the stele the horizontal break in the middle follows the contour of the woman's right arm, while the upper break spares the outline of her nose and forehead.

With regard to the material for the two "thrones", I believe that it was probably (broken) water basins. ${ }^{107}$ It would be natural to find such artefacts in the gardens of Sallust, fountains being staple features in Roman gardens. Unlike sarcophagi, for instance, which have more or less standard measurements, water basins were made to fit into a specific architectonic context, whether they formed part of a nymphaeum or stood on a street corner. Their measurements would therefore vary. If the "thrones" originally formed part of water basins, their irregular interiors would also be explained, for there would be no need to make their inner walls straight. ${ }^{108}$ Nobody bothers to look into a water basin as long as it does not leak.

The two "thrones" must have come from two different water basins. The walls of the basin used for the Ludovisi "throne" were thinner than those of the Boston "throne". ${ }^{109}$ The relief therefore had to be lower in certain sections, especially on the bottom front. The Boston "throne" was carved from part of a basin which had evidently been broken off in an irregular line, since its left flank is much shorter than the right one.

The Esquiline stele can perhaps be regarded as a test. If it passed, the time had come to launch a new and more lucrative monument, the Ludovisi "throne". In such cases, several people had to be paid: the material executioners (in this case the sculptors), one or more archaeologists and/or art historians to guide them with regard to style and iconography, intermediaries who attended to the sale, and, if necessary, people who were willing to confirm that

\footnotetext{
${ }^{106}$ According to La Rocca 1997, 37, traces of a painted kymation were found on the base of the stele after it had been cleaned. M. Bell III noted restaurations, according to him ancient (Bell III 1998, 312-313). The stele has a clamp hole (now filled up) in one of the short sides, and a fairly large round hole at the back, They are difficult to reconcile with a free-standing stele, and rather suggest that the original piece was connected to something. Already Ghirlandini (1893, 166-167) remarked that the base of the stele was unusual.

${ }^{107}$ P. Cellini tells that Ugo Janolo, the son of Alessandro Jandolo, claimed that the Boston "throne" was found in the gardens of the convent of San Isidoro, "tutto coperto dal tartaro delle acque, si diceva fosse stato trovato murato a modo di rustic fontanile e abbeveratorio" (Cellini 1955, 45). Even if the reliefs were incrusted, it seems unlikely that nobody would have noticed them earlier, so I believe that we have a slip of the tongue of Cellini's informant: the material for the Boston "throne" was an artefact used as a watering trough. Probably it was employed as a fountain basin originally.

${ }^{108}$ For the irregular interior of the Boston "throne" see Andreae 1997, 72, Fig. 1.

${ }^{109}$ The measurements of the two "thrones" are given by Carpenter 1941, 49, and von Gerkan 1929, among others. The easiest way to observe the differences is perhaps to look at the illustration in Studniczka 1911, 84, Fig. 19.
} 
the item had been in their family's possession for a long time. If the forgery did not just materialize in an antiquity shop, but was supposed to have been found in a determined area and at a certain time, it was necessary to bribe workmen to say that they had been present at the time of the discovery. The person(s) in charge of the consortium must have had a network of useful persons who could be summoned when needed.

The sculptors working on the Ludovisi "throne" were good at fashioning human bodies (especially females) and draperies, but they probably had no expert on architectural sculpture among them. The blank spaces left on the Ludovisi "throne" indicate that they had decorative ornaments in mind, but could not find a suitable artisan. Such a man joined the group only when work started on the Boston "throne". By combining features from Roman decorative sculpture, marble furniture and perhaps details from real furniture such as fulcra, he created quite a pleasing and convincing whole.

As time went by and their forgeries were accepted as genuine works, the members of the consortium became more daring. Just as a villain in an old-fashioned crime story becomes arrogant and leaves more traces, so the Boston "throne" left several puzzling details, both iconographic and stylistic. E.A. Gardner rightly speaks about "the beauty and simplicity of the Ludovisi relief" in contrast to the Boston "throne". 110 The latter exhibited too many disparaging features, and if one of them attracted suspicion, it was easy to suspect the whole monument. The members of the consortium were evidently aware of this, since they put the Boston "throne" in quarantine, as it were, withholding publication for a number of years. The Warren cup was even more audacious, but in that case the persons behind it could be certain that it would not be published.

Why was the Early Classical style used for the "thrones" and the Esquiline stele? I think the reason is that the man behind the blueprint for the stele and the Ludovisi "throne" was an expert on Attic vase painting of the transitional period from late Archaic to early Classical. The many parallels between the "thrones" and vase paintings were already pointed out by Studniczka. The women flanking "Aphrodite" on the Ludovisi throne are especially revealing.

Parallels to the contours of their legs seen through the fabric come from vase paintings. The designer of the Ludovisi "throne" based himself on motifs from vases, and in the drawing he left for the sculptors, he must have included the partial outline of the women's legs without realizing that this feature is not encountered in relief sculpture. For "Aphrodite"s head, which is raised and tilted slightly backwards, the designer may have been influenced by ecstatic maenads, which are often represented in Attic vase painting. B S. Ridgway noticed the resemblance between the head of "Aphrodite" and that of Penthesileia on the kylix by the Penthesileia Painter in Munich. ${ }^{111}$ It was published by O. Jahn in 1854, and was therefore available as a source of inspiration.

The designer(s) of the thrones must also have been familiar with Arretine ceramics and silver ware. The figures of seated musicians on Arretine ware may well have been among the sources of inspiration for those on the "thrones". Another detail is the fabric covering the

\footnotetext{
${ }^{110}$ Garnder 1913, 73.

${ }^{111}$ Ridgway 1970,50 with n. 7.
} 


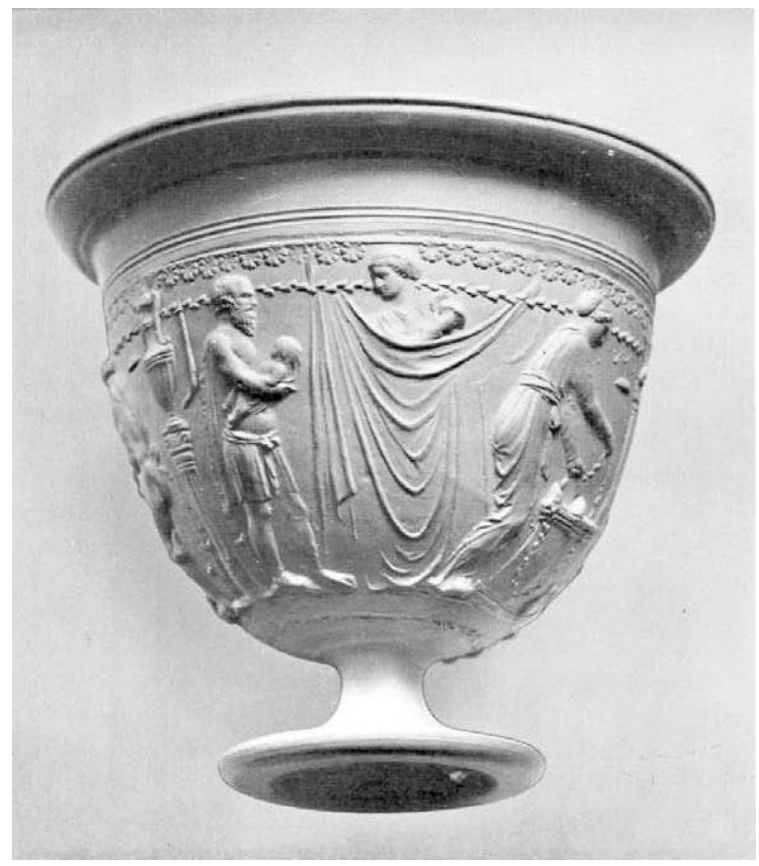

FIG. 12 - Matrix from Arretine bowl. From Mededelingen van het Nederlands Institut te Rome, 1937, Pl. VII.

lower part of the body of "Aphrodite". If her anatomy were carved down to the bottom, the relief would have had to be extremely low in contrast with that of her upper body, and she would be cut off abruptly above the knees. Better then to cover her lower body completely with a piece of cloth.

This covering fabric has been connected with pinakes from Locri, where one sees a woman on the left holding a piece of cloth (a cloak?) in front of her while Aphrodite, having just risen from the waves, runs towards a woman on the right. ${ }^{112}$ Locrian pinakes may have been known to the designer(s) of the Ludovisi throne. Some of the pinakes show thin, rippling folds like those covering the body of "Aphrodite", ${ }^{113}$ while others feature a fabric adhering closely to the body though the waist is bent, like the dress of the two lateral attendants on the "throne". ${ }^{114}$ As for the fabric covering "Aphrodithe"s lower body, a female figure from the Arretine repertory could also have served as a source of inspiration (FIG. 12). The woman in question is a cymbal player hidden by a drapery. ${ }^{115}$ In this case it would suffice to lower the cloth. The manner in which its folds are falling is close to the Ludovisi relief, while the fabric on the Locrian pinakes is held taut. I have already mentioned the cushions, which is a joining element of the two "thrones". They are in all probability taken over from Arretine ware, though they also occur in silver ware, which the Arretine masters often copied. ${ }^{116}$

Inspiration from small-scale art is often seen as typical of forgers, but to be credible, they also had to study sculpture in stone if they were fashioning works in that material. One favourite with the designer(s) of the "thrones" was the so-called Penelope, whose the hijab-like head-covering recurs on both monuments. The lock of hair descending to the breast of "Aphrodite" on the Ludovisi "throne" seems to have been borrowed from a Severizing version of "Penelope" in the Galleria delle statue in the Vatican (FIG. 5). This version has influenced the

\footnotetext{
${ }^{112}$ Prückner 1968, 36-38, Fig. 4; Guarducci 1985, 7-8, Figs. 9-10; Mertens-Horn 1997, 97, Fig. 7; Pileggi $2011,44$.

${ }^{113}$ Prückner 1968, Pls. 1:1, 3:2, 6:1-3, 7:6, 8:4-7, 13:1-3, 22:1, 24:3,7, 33:1,3; Guarducci 1985, 15-16, Figs. 17-21; Pileggi 2011, 19, 37, 18.

${ }^{114}$ Langlotz 1963, 73, Fig. 75; Prückner 1968, 39-40 Pl. 4:4; Pileggi 2011, 32.

${ }^{115}$ Porten Palange 2004, 240-241, Pl. 128, wTMF fr 1a; Porten Palange 2009, 61, P1. 30, Komb. Per 34.

${ }^{116}$ See a silver cup from the House of Menander in Pompeii: Maiuri 1933, 321-330, no. 5, Figs. 125-126, Pls. 31-33; Clarke 1993, 280, Fig. 10; Clarke 1998, 68-71, Fig. 23; Guzzo 2006, 206-207, no. 289.
} 
"bride" on the right flank of the Ludovisi "throne" and "Aphrodite" on the front of the Boston "throne".

The head of the Vatican statue is not the original one, but was added to the body later, probably at the beginning of the nineteenth century. ${ }^{117}$ It is a male head wearing a diadem, but the restorer covered it with a himation which he combined with that on the body. Consequently the statue appears as a female with the himation drawn over her head and another head-covering underneath. On the Ludovisi "throne" the edge of the himation forms a straight line, as it does in the Vatican version, and it is basically straight on the head of "Aphrodite" on the Boston "throne". None of these women looks sad; indeed, "Aphrodite" seems to smile.

"Persephone", her companion on the right side is different, however. Her head-covering is much closer to that of the real "Penelope", and she is clearly grieving. The reason why the Boston "throne" shows two versions of "Penelope" is probably the appearance of Studniczka's ground-breaking publication of her real head. It appeared in Antike Denkmäler in 1888 , in the period when the Boston "throne" is likely to have been planned (the work on it may already have started). Studniczka's discovery enabled the designer to include an up-todate "Penelope" for the grieving woman, while he preferred the old version for her companion. It is noted that forgers often used drawings and photos as models for their work, and the sculptors may have used the photos from Studniczka's publication. ${ }^{118}$

Another sculptural work which is related to the Ludovisi throne" is the above-mentioned Humphry Ward head, which furnishes the only parallel to Aphrodite's ear emerging through the locks of hair. The head is named after its former owner, who purchased it in Florence in 1892. ${ }^{119}$ According to the art dealer it had been bought from the Palazzo Borghese, where it had apparently attracted no attention. ${ }^{120}$ Is the Humphry Ward head also a product of the workshop which made the two "thrones"? If so, its sculptors were able to produce convincing works not only in the Severe style, but also in a ripe Classical manner.

If one assumes that the Esquiline stele and the two "thrones" are forgeries, who can have been behind them? The Esquiline stele reveals inspiration from two sources, relief sculpture and Athenian vase painting of the Late Archaic/Early Classical period. A quietly standing figure such as a hetaera on a kylix by Peithinos could have served as a point of departure. ${ }^{121}$ She wears a sakkos and the folds of her himation are bunched up behind her neck, a typical feature of Athenian vase paintings of the period. The designer of the stele has given the girl a dove in one hand while the other is pulling out her dress - another typical motif in vase painting. One would hardly have suspected this figure if it had not been for the similarities to the Ludovisi and Boston "thrones" referred to above.

\footnotetext{
${ }^{117}$ Studniczka 1988, 17.

${ }^{118}$ Eisenberg 1997, 21, suggested that the "impossible" position of the right foot of the flute-player on the Ludovisi "throne" may have been inspired by photos in three-quarter view of the "Penelope" in the Galleria delle Statue, where the right foot appears to be very close to the left one.

${ }^{119}$ Pasquier 1997, 54.

${ }^{120}$ Sellers 1894,198 . It seems odd that a head in a well-known collection should not have been mentioned by anyone, but Sellers explains it by the fact that the head "was tilted upwards at a very unpleasing angle and restored with a nose totally out of keeping with the style and proportions of the face: disfigurements which perhaps account for its neglect by the many archaeologists which must have seen it in its old Roman home".

${ }^{121}$ See for instance Hartwig 1893, Pl. XXV.
} 
The Ludovisi "throne" shows a clear relationship with Early Classical Attic vase painting, and it is also indebted to fifth century sculpture, notably the so-called Penelope. Other sculptural parallels, however, suggest far later times, such as the Severizing "Electra" in Naples and the Esquiline Venus. Also Etruscan mirrors and Arretine ware furnish parallels to certain features of the "throne". It is difficult to say whether the creator of the Ludovisi "throne" has branched out from his original themes: fifth century vase painting and sculpture, or whether he has been joined by a more imaginative person.

More imagination was necessary because of the more complex shape of the object used as material. The lateral panels could be filled with single figures, but the front demanded something more. The solution was to present three figures linked together by the actions of their arms. The motif suggested various mythological scenes which were already known, without reproducing any of them in a clearly recognizable manner. Does the Ludovisi "throne" represent the birth of Aphrodite, Persephone rising from the underworld, a mythological birth or even a funeral? Personally I think that Aphrodite's birth is intended, because of the pebbles under the nude feet of the attendants. It would have given the spectator associations to a beach or a shore. In Greek art the shore was indicated by rocks or crags, ${ }^{122}$ but the designer may not have reflected on this. He was not interested in impressing archaeologists, but wealthy buyers. "Mythological" scenes which are sufficiently vague to escape confrontation with genuinely Ancient representations, are often preferred by forgers.

This is also the case with the Boston "throne", where the motif on the front is generally supposed to be a kerostasia or pshychstasia, but where none of the solutions is really satisfactory. Two male figures are introduced, and the decorative repertoire is augmented by the addition of palmettes, volutes and other decorative elements, all inspired from Roman sources. These different sources of inspiration would sooner or later have attracted suspicion. The consortium behind the "throne" was probably aware of this, which is why it chose the one buyer who would not exhibit the reliefs in a museum.

Who could be behind the "thrones"? To Margherita Guarducci Helbig and Hartwig were the culprits, with Hartwig as the main actor, ${ }^{123}$ while others have given Hartwig's name alone. ${ }^{124}$ If the Esquiline stele and the Ludovisi "throne" are the products of the same workshop as the Boston "throne", Hartwig and his friend Hauser must be eliminated. They took up residence in Rome in 1892, two years before the Boston "throne" was put on the market. Even if one believes that the two were responsible only for the latter, two years seem too short a time. During that period Hartwig and Hauser would have had to be acquainted with the legal and illegal art market, with those in charge of the "excavations" in the Roman horti, and last but not least, they would have had to find a workshop specializing in forgeries, make a suitable design and follow up the work.

Helbig came to Rome already in 1862 . He would have ample time to familiarize with the Roman milieu in all its legal and illegal aspects. He knew several of the Roman noble families, and might have been able to convince the Ludovisi family to accept the first "throne"

\footnotetext{
${ }^{122}$ Compare Donati and Pasini 1997, 18-20, 70, 103, 106, 138, 146, 151, 162, 168.

${ }^{123}$ Guarducci 1980, 506-507; Guarducci 1987, 58-59.

${ }^{124}$ von Gerkan 1961, 154; Alscher 1963, 17. Hartwig's friend Hauser is generally regarded as a marginal figure, but since the two were intimate friends, it is difficult to see how Hauser could have been kept out of the project. In his letter to C. Jacobsen Hartwig asks him to regard himself and Hauser "as one person" (Moltesen 1990, 37).
} 
with a view to selling it. Helbig kept a close eye on the works going on in the areas which were being developed, hoping to get suitable pieces of ancient sculpture for Carl Jacobsen. He could therefore have been able to offer photos of the decorative panel found in 1888, so that its palmettes could be included in the decorative repertoire of the Boston "throne". As a scholar, he would probably have known Studiczka's article about "Penelope" from the same year, just in time to add a correct version of the type to the Boston "throne".

But was Helbig really responsible for the "thrones" and the Esquiline stele? Their designer was evidently a man who specialized in small-scale art such as Greek vase painting and Roman Arretine ware. Helbig's main interests were Campanian wall-painting and ancient sculpture in general, though he also purchased Etruscan artefacts for Carl Jacobsen. Since Greek vases were found in Etruscan tombs, Helbig must have seen many of them when he went looking for Etruscan items in the various antiquarians' shops. Still, he does not seem to be the kind of specialist who would instinctively draw the outline of the legs through the dress of "Aphrodite"s attendants on the blueprint for the Ludovisi throne.

Personally I think that an Italian archaeologist was behind the "thrones" and the Esquiline stele. He would have the necessary knowledge and network to pull off the bluff successfully, but he could of course not approach the art market with "ancient" masterpieces which had allegedly been excavated in Rome. For this task he needed intermediaries, preferably foreigners, and in that respect resident Privatgelehrter like Helbig, Hartwig and Hauser would have been suitable. It could in fact be that the mysterious Italian on behalf of whom Helbig claimed to act when the Boston "throne" was sold, was, in fact, an Italian archaeologist who could get his share in the business only in this roundabout way.

As for the Warren cup, the question about its authenticity is not of paramount importance for the Ludovisi and Boston "thrones". Their affinities with the Warren cup suggest that they were partly inspired from Roman works like Arretine ware and silver, and that they therefore cannot be Classical Greek works. However, certain features of the cup, like the treatment of the bedclothes and the hangings, give associations to the "thrones". The latter were clearly designed by an expert in Athenian vase painting, and one seems to sense such a figure behind the Warren cup, too. The strap gripped by the youth in scene A is found in erotic scenes on Athenian red figure vases, ${ }^{125}$ and such a feature would have been known only to scholars.

Marabini Moevs has given the name of Fausto Benedetti, ${ }^{126}$ a shady figure and a friend of Helbig. He might have been involved with the fabrication of the Warren cup, but he seems to have lacked real erudition. He could, however, have suggested homoerotic motifs for the cup's decorations, since he was a close friend of Warren and knew his tastes. With regard to the ambience which produced the Warren cup, Marabini Moevs has suggested the School for Applied Arts in the Via Capo Case in Rome, and the workshop of Augusto Castellani, which produced numerous pieces of jewelry inspired by ancient models. ${ }^{127}$

If it is a forgery, the Warren cup was probably produced not too long after Warren's purchase of the Boston "throne", in a period when he became interested in Roman silver work as a consequence of the discovery of the Boscoreale treasure. However, if Warren was notified about the silver cup only in 1911, its artificers waited a long time. This could partly have

\footnotetext{
${ }^{125}$ Marabini Moevs 2008, 6, Fig. 10.

${ }^{126}$ Marabini Moevs 2008, 10.

${ }^{127}$ Marabini Moevs 2008, 10-11.
} 
been due to the necessary preparation of the cup, which must have been buried for some time in order to acquire a convincing patina, ${ }^{128}$ but the persons behind the cup could also have been waiting for a propitious date. It is perhaps not fortuitous that Warren was offered the cup in 1911, which marked the publication of Studniczka's article, where the Boston "throne" was declared a masterpiece of Greek sculpture. This was gratifying for Warren, who could see himself as a great collector with a flair for antiquities. An offer of a new masterpiece may therefore have found a favourable reception.

In her article on the lyre player on the Boston "throne", L. Vlad Borrelli writes that the detractors of the monument cannot come up with proofs of its $19^{\text {th }}$ century dating, only circumstantial evidence. The combined weight of this evidence may strengthen the suspicions, however. ${ }^{129}$ This is also true of the Ludovisi "throne", where an overwhelming amount of circumstantial evidence will be needed to challenge its position as a genuine 5th century work. I have here added some evidence, though I am aware that to settle the matter, something more clamorous is needed, such as new methods for dating marble sculpture, or the discovery of a correspondence where the names of the implicated persons are revealed.

Siri Sande

The Norwegian Institute in Rome

University of Oslo

siri.sande@roma.uio.no

\footnotetext{
${ }^{128}$ Franchi 2008, 15, suggests "qualche mese, in condizioni studiatamente e artificiosamente rese estremi”, but the cup could also have been buried for a longer time under less extreme conditions.

${ }^{129}$ Borrelli 1993, 56.
} 


\section{BIBLIOGRAPHY}

AaVv 1995: Museo Chiaromonti 1-3, Berlin-New York. AaVv 1997: Il Trono Ludovisi e il Trono di Boston, Venezia. AaVv 2011: Palazzo Altemps. Le collezioni, Milano.

Alscher, L. 1963: Götter vor Gericht, Berlin.

Amelung, W. 1903-1908: Die Skulpturen des Vatikanischen Museums I-II, Berlin.

Andreae, B. 1997: "La Cassazione del giudizio di Ludger Alscher sul Trono di Boston”, in AaVv 1997, 71-75.

Ashmole, B. and Yalouris, N. 1967: Olympia. The Sculptures of the Temple of Zeus, London.

Barbanera, M. 2016: "Ambiguità del falso", Archeo 375, 2839.

Baroni, F. 1961: Osservazioni sul "Trono di Boston", Roma.

Bell, M. III 1998: "Le stele greche dell'Esquilino e il cimitero di mecenate", in Cima and La Rocca 1998, 294-314.

Berger, E. 1968: "Die Hauptwerke des Basler AntikenMauseums zwischen 460 und 430 v. Chr.", Antike Kunst $11,62-81$.

Bieber, M. 1961a: The History of the Greek and Roman Theater, Princeton, N. J.

Bieber, M. 1961b: The Sculpture of the Hellenistic Age (Rev. Ed.), New York.

Borda, M. 1953: La scuola di Pasiteles, Bari.

Borrelli, L. Vlad 1993: "Postilla alla questione del "trono" di Boston", BdA 77, 55-62.

Bottini, A. (ed.) 2005: Il rito segreto: Misteri in Grecia e a Roma, Milano.

Bottini, A. 2011: "Il Trono Ludovisi: una proposta di ricostruzione", in Masseria and Loscalzo 2011, 11-17.

Buitron-Oliver, D. 1995: Douris. A Master-Painter of Athenian Red Figure Vases (Forschungen zur antiken Keramik, II Reihe, 9), Mainz.

Cain, H.-U. 1995: Römische Marmorkandelaber, Mainz.

Carpenter, R. 1941: Observations on Familiar Statuary in Rome, MAAR XVIII.

Cellini, P. 1955: "Ne sutor ultra crepidem", Paragone V, 65, 42-47.

Charbonneaux J., 1963: La sculpture Grecque et Romaine au Musée du Louvre, Paris.

Cima, M. and La Rocca, E. 1986, Le tranquille dimore degli dei. La residenza imperiale degli horti Lamiani, Venezia.

Cima, M. and La Rocca, E. (eds.) 1998: Horti Romani. Atti del Convegno Internazionale Roma 4-6 maggio 1995, Roma.

Cima, M. and Talamo, E. 2008: Gli horti di Roma antica, Milano.

Clarke, J.R. 1993: "The Warren Cup and the Contexts for Representations of Male-to-Male Lovemaking in Augustan and Early Julio-Claudian Art", ArtB LXXV, 275-294.

Clarke, J.R. 1998: Looking at Lovemaking: Constructions of Sexuality in Roman Art, 100 B.C. to A.D. 250, Berkeley.

Colin, J. 1946: "Les trones Ludovisi-Boston et les temples d'Aphrodite Erycine", $R A$ XX, 23-42 and 139-172.
Donati, A. and Pasini, P. (eds.) 1997: Pesca e pescatori nell'antichità, Milano.

Eisenberg, J.R. 1997: "The Ludovisi and Boston Thrones and their 19th Century Sources", in AaVv 1997, 19-33.

Faust, S. 1989: Fulcra: figürlicher und ornamentaler Schmuck an antiken Betten, Mainz.

Franchi, C. 2008: "Sulla technica di realizzazione del Calice Warren", BdA 146, 14-16.

Fuchs, W. 1959: Die Vorbilder der neuattischen Reliefs, Berlin.

Galinsky, K. 1996: Augustan Culture, Princeton, New Jersey.

Gardner, E.A. 1913: "The Boston counterpart of the "Ludovisi throne", JHS 33, 73-83.

Gerkan, A. von 1929: "Untersuchungen am Ludovisischen und Bostoner Relief ", ÖJh 25, 125-172.

Gerkan, A. von 1969: "Das Ludovisische Relief und sein angebliches Gegenstück", RM 67, 150-161.

Ghirandini,G. 1883: "Di una stele sepolcrale greca scoperta in Rom”, BCom XI, 144-172.

Giuliano, A. (ed.) 1995: Museo Nazionale Romano. Le sculture I, 12. Magazzini. Sculture greche del V secolo, Parte I, Roma.

Guarducci, M. 1980: "La cosidetta Fibula Prenestina: antiquari, eruditi e falsari nella Roma dell'Ottocento", MemAccLinc ser. VIII, 25, 411-539.

Guarducci, M. 1985: "Il "Trono Ludovisi e L'Acrolito Ludovisi", due pezzi insigni del Museo Nazionale Romano", BdA 33-34, 1-20.

Guarducci, M. 1987; "Il cosidetto Trono di Boston", BdA 43, 49-62.

Guzzo, P. G. (ed.) 2006: Argenti a Pompei, Milano.

Hamiaux, M. 1992: Les sculptures grecques, I. Des origines à la fin du IVe siècle avant J.-C., Paris.

Hartswick, K. J. 2004: The Gardens of Sallust. A Changing Landscape, Austin (Texas).

Hartwig, P. 1893: Meisterschalen der Blützeit des strengen rothfigurischen Stils, Stuttgart-Berlin.

Häuber, Ch. 1986a: "Il programma scultureo", in Cima and La Rocca 1986, 79-102.

Häuber, Ch. 1986b: "I nuovi ritrovamenti (dopo il 1870)", in Cima and La Rocca 1986, 173-200.

Herrmann, J. J. 1997: "The authenticity of the Boston Throne: a view from Boston", in AaVv 1997, 13-17.

Langlotz, E. 1963: Die Kunst der Westgriechen in Sizilien und Unteritalien, München.

La Rocca, E. 1997: "Troni degli horti Sallustiani ed il santuario di Venere Erycina: alcune proposte", in AaVv 1997, 35 47.

Leipen, N. et al. 1984: Glimpses of excellence: a selection of Greek vases and bronzes from the Elie Borowski collection, Toronto.

Lippold, G. 1956: Die Skulpturen des Vatikanischen Museums III, 2, Berlin. 
Lott, J. B. 2004: The Neighborhoods of Augustan Rome, Cambridge.

Maiuri, A. 1933: La Casa del Menandro e il suo tesoro di argenteria, 1-2, Roma.

Marabini Moevs, M.T. 2008: "Per una storia del gusto: riconsiderazioni sul Calice Warren", $B d A$ 146, 1-14.

Masseria, C. and Loscalzo, D. (eds.) 2011: Miti di guerra, riti di pace, Bari.

Mertens-Horn M. 1997: "Rappresentazioni di scene sacre", in AaVv 1997, 94-106.

Moltesen, M. 1990: "Una nota sul Trono Ludovisi e sul Trono di Boston: la 'connection' danese", BdA 76, 27-46.

Moltesen, M. 2012: Perfect Partners. The Collaboration between Carl Jacobsen and his Agent in Rome, Wolfgang Helbig in the Formation of the Ny Carlsberg Glyptotek 1887-1914, Copenhagen.

Moreno, P. 1994: Scultura ellenistica I-II, Roma.

Moretti, G. 1948: Ara Pacis Augustea, Roma.

Nash, E. 1959: "Über die Auffindung und den Erwerb des „Bostoner Thrones”, RM 66, 104-137.

Neer, R. T. 2002: Style and Politics in Athenian VasePainting. The Craft of Democracy, ca. 530-460 B.C.E., Cambridge.

Orlandini, P. 1997: "I due Troni: Religiosità e stile, sincerità e aritificio", in AaVv 1997: 67-69.

Paribeni, E. 1953: Museo Nazionale Romano. Sculture greche del V secolo, Roma.

Pasquier, A. 1997: "Le Triptyque Ludovisi, le Trône de Boston et leur controverse dans les sources archéologiques Francaises", in AaVv 1997, 49-54.

Petersen, E. 1892: “Aphrodite”, $R M$ VII, 33-80.

Pfühl, E. and Möbius, H. 1977: Die ostgriechischen Grabreliefs I, Mainz.

Pileggi, R. S. 2011: I pinakes di Locri Epizefiri, Reggio Calabria.

Pollak, L. and M.M. Guldan 1994: Ludwig Pollak. Römische Memoiren: Künstler, Kunstliebhaber und Gelehrte 18931943, ed. M. Merkel Guldan, Roma.

Porten Palange, F. P. 2004, Katalog der Punzmotive in der arretinischen Reliefkeramik, Mainz.

Porten Palange, F.P. 2009: Die Werkstätten der arretinischen Reliefkeramik, Mainz.

Prückner, H. 1968: Die lokrischen Tonreliefs. Beitrag zur Kultgeschichte von Lokroi Epizephyroi, Mainz.

Reinach, S. 1888: "Courrier de l'art antique", GazBA, 60-77.

Richter, G. M. A. 1965: The Portraits of the Greeks I-III, London.
Richter, G. M. A. 1966: The Furniture of the Greeks, Etruscans and Romans, London.

Richter, G.M.A. and Smith, R.R.R. 1984: The Portraits of the Greeks. Gisela M.A. Richter. Abridged and revised by R. R. R. Smith, Oxford.

Ridgway, B.S. 1970: The Severe style in Greek sculpture, Princeton, New Jersey.

Ridgway, B.S. 1977: The Archaic style in Greek sculpture, Princeton, New Jersey.

Ridgway, B.S. 1981: Fifth-century styles in Greek sculpture, Princeton, New Jersey.

Ridgway, B.S. 2002: Hellenistic sculpture III. The styles of ca. 100-31 BC, Madison (Wisconsin).

Sande, S. 1995: "An Old Hag and her Sisters", SymbOslo LXX, 30-53.

Sellers, E. 1894: "Greek Head in the possession of T. Humphry Ward, Esq.”, JHS 14, 198-205.

Simon, E. 1959: Die Geburt der Aphrodite, Berlin.

Simon, E. 1987: "Kriterien zur Deutung ,Pasitelischen" Gruppen", JdI 102, 291-304.

Soleti, V.M. 2003: "Gli studi sul Trono Ludovisi e sul Trono di Boston dalla scoperta al 2000", Annali della Facoltà di Lettere e Filosofia, Università degli Studi di Bari 46, 5-116.

Spinola, G. 2004: Il Museo Pio Clementino 3, Città del Vaticano.

Studniczka, F. 1888: Antike Denkmäler, 17-19, A, Pl. 31 A, Figs. A1-A2.

Studniczka, F. 1911: "Das Gegenstück der Ludovisischen "Thronlehne", JdI XXVI, 50-192.

Talamo, E. 1998: "Gli horti di Sallustio a Porta Collina", in Cima and La Rocca 1998, 113-169.

Torrelli, M. 2011: "Il ,Trono Ludovisi' e la tradizione cultuale orientale", in Masseria and Loscalzo 2011, 19-22.

Viscogliosi, A. 1996: Il tempio di Apollo in Circo e la formazione del linguaggio architettonico augusteo, Roma.

Visconti, G. 1887: "Un singulare monumento di scultura ultimamente scoperto negli Orti Sallustiani”, BCom XV, 267-274

Williams, D. 2006: The Warren Cup, London.

Wrede, H. 1991: "Matronen im Kult des Dionysos", JdI 98, 163-188.

Zanker, P. 1974: Klassizistische Statuen: Studien zur Veränderung des Kunstgeschmacks in der römischen Kaiserzeit, Mainz.

Zanker, P. 1987: Augustus und die Macht der Bilder, Mainz. 
